\title{
Brain Tumor-Derived Extracellular Vesicles as Carriers of Disease Markers: Molecular Chaperones and MicroRNAs
}

\author{
Alessandra Maria Vitale ${ }^{1,2,+}{ }^{\mathbb{C}}$, Radha Santonocito ${ }^{1,+}{ }^{\text {, Giuseppe Vergilio }}{ }^{1}$, \\ Antonella Marino Gammazza ${ }^{1}$, Claudia Campanella ${ }^{1}$, Everly Conway de Macario ${ }^{3}$, \\ Fabio Bucchieri ${ }^{1}$, Alberto J. L. Macario ${ }^{2,3}$ (D) and Celeste Caruso Bavisotto 1,2,*iD \\ 1 Department of Biomedicine, Neuroscience and Advanced Diagnostics (BIND), Section of Human Anatomy, \\ University of Palermo, 90127 Palermo, Italy; alessandramaria.vitale@unipa.it (A.M.V.); \\ radha.santonocito@unipa.it (R.S.); peppe04@tiscali.it (G.V.); antonella.marinogammazza@unipa.it (A.M.G.); \\ claudia.campanella@unipa.it (C.C.); fabio.bucchieri@unipa.it (F.B.) \\ 2 Euro-Mediterranean Institute of Science and Technology (IEMEST), 90139 Palermo, Italy; \\ Ajlmacario@som.umaryland.edu \\ 3 Department of Microbiology and Immunology, School of Medicine, University of Maryland at \\ Baltimore-Institute of Marine and Environmental Technology (IMET), Baltimore, MD 21202, USA; \\ econwaydemacario@som.umaryland.edu \\ * Correspondence: celestebavisotto@gmail.com or celeste.carusobavisotto@unipa.it; Tel.: +39-091-2386-5700 \\ + These authors contributed equally to this work.
}

Received: 6 September 2020; Accepted: 1 October 2020; Published: 5 October 2020

\begin{abstract}
Primary and metastatic brain tumors are usually serious conditions with poor prognosis, which reveal the urgent need of developing rapid diagnostic tools and efficacious treatments. To achieve these objectives, progress must be made in the understanding of brain tumor biology, for example, how they resist natural defenses and therapeutic intervention. One resistance mechanism involves extracellular vesicles that are released by tumors to meet target cells nearby or distant via circulation and reprogram them by introducing their cargo. This consists of different molecules among which are microRNAs (miRNAs) and molecular chaperones, the focus of this article. miRNAs modify target cells in the immune system to avoid antitumor reaction and chaperones are key survival molecules for the tumor cell. Extracellular vesicles cargo reflects the composition and metabolism of the original tumor cell; therefore, it is a source of markers, including the miRNAs and chaperones discussed in this article, with potential diagnostic and prognostic value. This and their relatively easy availability by minimally invasive procedures (e.g., drawing venous blood) illustrate the potential of extracellular vesicles as useful materials to manage brain tumor patients. Furthermore, understanding extracellular vesicles circulation and interaction with target cells will provide the basis for using this vesicle for delivering therapeutic compounds to selected tumor cells.
\end{abstract}

Keywords: brain tumors; extracellular vesicles; miRNA; molecular chaperones; diagnostic tools; drug delivery

\section{Introduction}

Brain tumors entail high mortality and morbidity worldwide, with 296,851 new cases and 241,037 deaths in 2018, according to the Global Cancer Observatory [1]. Currently, the diagnosis of brain tumors is based on neuroimaging techniques complemented by biopsy. However, these methods are not always applicable because of the type and/or the localization of the tumor. Therapeutic choices include surgery, and radio-, chemo-, and immunotherapy. However, several complications can occur, 
such as venous thrombosis, pulmonary embolism, intracranial bleeding, wound and systemic infection, seizures, depression, deteriorating neurologic conditions, and adverse drug reaction [2]. This worrying scenario points to the need for novel methods that will allow earlier and more accurate diagnosis and better patient monitoring and treatment than those currently available.

Remarkable achievements in the molecular and genetic fields have opened new frontiers in the management of brain tumors, including the identification of new diagnostic and prognostic molecular biomarkers released by the tumor. Noteworthy examples of these biomarkers are carried by extracellular vesicles (EVs), released by tumors. EVs, which are considered mediators of intercellular communication, carry bioactive molecules between cells close by or distant, affecting physiological and pathological processes in recipient cells [3-9]. MicroRNAs (miRNAs) and molecular chaperones are among the bioactive molecules carried by EVs that affect, either directly or indirectly, cancer initiation, cell proliferation and growth, and metastasization [10-14]. Consequently, specific miRNAs and molecular chaperones have been suggested as targets for analysis that can provide useful information for differential diagnosis, assessing prognosis and response to treatment, and for developing novel therapies [15]. One added advantage is that EVs can be obtained from biological fluids with minimally invasive procedures.

Here, we discuss the role of EVs in the pathogenesis of brain tumors, summarizing current knowledge regarding their miRNAs and molecular chaperones cargo. We examine their role in the development of brain tumors, and their impact on the tumor microenvironment.

\section{Intercellular Communication: EVs}

Cells can share between them biological information using lipids, proteins, or nucleic acids as mediators, which are carried within small, nano-to-micrometer lipid-membraned EVs released by them [16]. EVs are present in biological fluids, including blood, urine, milk, saliva, and cerebrospinal, amniotic, and seminal fluids [17].

EVs play a key role in intercellular communication in physiological and pathological cellular processes $[18,19]$ and are considered a valuable source of useful biomarkers [20-22].

The International Society for Extracellular Vesicles (ISEV) encourages the use of the term "extracellular vesicles (EVs)" as a generic term for all secreted vesicles, considering the lack of consensus for the identification of specific markers to distinguish between the different subtypes of EVs [23]. Formerly, the nomenclature assigned to EVs subgroups was based on differences in the size and formation mechanism [23], and classified them into three main groups: 1. shedding microvesicles, with a size range of 100-1000 nm [24]; 2 . apoptotic bodies (1-5 $\mu \mathrm{m}$ diameter), released into the extracellular environment by dying cells [25]; and 3. exosomes, small vesicles between 30-150 $\mathrm{nm}$ in size produced from the endosomal compartment [23].

However, distinguishing between the various groups is still problematic, so in this review, we refer to EVs, regardless of the classification used in the works cited, which often do not report specific data that would allow a precise identification of EVs subtypes.

It is known that EVs are involved in numerous physiological and pathological processes, including immune response, signal transduction, tumor progression, and inflammation [4]. Consequently, EVs have potential as carriers of molecular biomarkers for diagnosis and prognosis in a range of conditions, including cardiovascular, renal, and neurodegenerative diseases, and cancer [26], or as transporters of therapeutic agents $[27,28]$.

EVs carry proteins, lipids, mRNA, and miRNAs, and their contents depend on the type and function of the cell in which they originate [29].

EVs contain substantial amounts of different RNA species, such as miRNA, mRNA, ribosomal RNA, long noncoding RNA, transfer RNA, and small nuclear RNA [30]. Although mRNAs are the most abundant class of RNAs in EVs, many studies have focused on miRNAs because of their apparent role in cancer progression. Vesicular miRNAs were suggested as novel diagnostic, prognostic, and predictive biomarkers in several common cancers [31]. 
Exosomes are highly enriched in proteins with various functions, such as proteins associated with cell membrane interaction, invasion, and fusion, e.g., the tetraspanins CD9, CD63, CD81, and CD82. The tetraspanins CD9, CD63, and CD81 are used as specific markers [23]. Furthermore, EVs contain proteins involved in maintenance of cell homeostasis and protection of cells against stress/apoptosis, e.g., molecular chaperones, some of which are called heat shock proteins (Hsp). Hsp60, Hsp70, and Hsp90 are the most commonly present Hsps in EVs and are among the most used vesicular markers [32].

\section{3. miRNAs and Molecular Chaperones in Brain Tumors}

Brain tumors are a heterogeneous group of neoplasms that differ in etiology, morphology, clinical manifestations, prognosis, and treatment. They were initially classified by the World Health Organization (WHO) according to their histologic features and presumed cellular origin. This type of characterization was the main tool used for many years in the diagnosis and management of patients, including decision on treatment strategy [33-36] (Table 1). However, increasing genetic and epigenetic discoveries have shown that a classification only based on histopathological findings fell short of the mark. For this reason, in 2016, the WHO formulated an updated classification, which went beyond the old principle of diagnosis based only on microscopy and incorporated molecular parameters to define brain tumors entities. This new classification allows a more objective and accurate diagnosis, ensuring a more accurate assessment of prognosis and treatment response than the old one [37].

Brain tumors can be either benign (noncancerous), or malignant (cancerous). The latter can be distinguished into primary, arising directly within the brain, and secondary, namely metastatic brain tumors derived from other parts of the body that have metastasized to the brain [2,38-40] (Table 1). Up to half of the metastatic brain tumors derive from lung cancer. Other types of tumors that commonly spread to the brain include melanoma, and breast, kidney, and colon cancer, although determining the site of the primary tumor is often difficult [38,41-44].

Genetic and environmental factors are implicated in the onset of primary brain tumors. The former are exemplified by neurofibromatosis types 1 and 2, adenomatous polyposis syndrome, tuberous sclerosis, nevoid basal cell carcinoma syndrome, Turcot syndrome, Li-Fraumeni syndrome, and von Hippel-Lindau syndrome, whereas those linked to environmental factors are exemplified by those caused by ionizing radiation, and they are all considerably less frequent than secondary tumors (Table 1) [45-51] (Table 1).

Table 1. Characteristics of the most common primary brain tumors.

\begin{tabular}{|c|c|c|c|c|}
\hline Tumor & Cell of Origin & Molecular Features & Clinical Features & Ref. \\
\hline Astrocytomas & & & \multirow{9}{*}{$\begin{array}{c}\text { Astrocytomas, } \\
\text { oligodendrogliomas, } \\
\text { and ependimomas are } \\
\text { gliomas that originate in the } \\
\text { glia and are extremely } \\
\text { invasive and malignant. } \\
\text { Main symptoms are } \\
\text { headache, seizures, nausea, } \\
\text { vomiting, disturbed } \\
\text { vision, tingling } \\
\text { sensations, weakness, } \\
\text { difficult ambulation. }\end{array}$} & \multirow{9}{*}{ [52-64] } \\
\hline Diffuse astrocytoma (WHO Grade II); & & p16 deletion & & \\
\hline Anaplastic astrocytoma (WHO & & p53 mutation & & \\
\hline Grade III); Pilocytic astrocytoma & Astrocyte & PTEN mutation & & \\
\hline $\begin{array}{l}\text { (WHO Grade I); Glioblastoma } \\
\text { multiforme (WHO Grade IV); }\end{array}$ & & $\begin{array}{l}\text { EGFR amplification } \\
\text { IDH1 mutation }\end{array}$ & & \\
\hline Gliosarcoma (WHO Grade IV) ${ }^{1}$. & & & & \\
\hline Oligodendrogliomas & & PEG3 deletion & & \\
\hline $\begin{array}{c}\text { Oligodendroglioma (WHO Grade II); } \\
\text {-Anaplastic Oligodendroglioma; } \\
\text { (WHO Grade III). }\end{array}$ & Oligodendrocyte & $\begin{array}{l}\text { EGFR amplification } \\
\text { p53 mutation } \\
\text { p16 deletion } \\
\text { IDH1, IDH2 mutation }\end{array}$ & & \\
\hline $\begin{array}{c}\text { Ependymomas } \\
\text { Subependymoma (WHO Grade I); } \\
\text {-Myxopapillary ependymoma (WHO } \\
\text { Grade I); Ependymoma (WHO } \\
\text { Grade II); Ependymoma, RELA } \\
\text { fusion-positive (WHO Grade II or III); } \\
\text { Anaplastic ependymoma } \\
\text { (WHO Grade III). }\end{array}$ & Ependymal cell & $\begin{array}{c}\text { NF2 mutation } \\
\text { MT3 underexpression } \\
\text { hTERT overexpression } \\
\text { miR-485-5p downregulation } \\
\text { IGF1 upregulation } \\
\text { p16 deletion } \\
\text { EGFR amplification }\end{array}$ & & \\
\hline
\end{tabular}


Table 1. Cont.

\begin{tabular}{|c|c|c|c|c|}
\hline Tumor & Cell of Origin & Molecular Features & Clinical Features & Ref. \\
\hline $\begin{array}{c}\text { Meningiomas } \\
\text { Meningioma (WHO Grade I); } \\
\text { Atypical meningioma (WHO } \\
\text { Grade II); Anaplastic meningioma } \\
\text { (WHO Grade III). }\end{array}$ & Meningeal cell & $\begin{array}{l}\text { NF2 mutation } \\
\text { DAL1 loss } \\
\text { PTEN mutation } \\
\text { p16 deletion } \\
\text { EGFR overexpression }\end{array}$ & $\begin{array}{l}\text { Meningiomas are tumors of } \\
\text { the meninges. Main } \\
\text { symptoms are headache, } \\
\text { seizures, psychotic-motor } \\
\text { disabilities, mental } \\
\text { weakening, personality } \\
\text { changes, visual disorders, } \\
\text { language dysfunction. }\end{array}$ & {$[37,65-69]$} \\
\hline $\begin{array}{c}\text { Medulloblastomas } \\
\text { Medulloblastoma (WHO Grade IV); } \\
\text { Desmoplastic/Nodular } \\
\text { Medulloblastoma (WHO Grade IV); } \\
\text { Medulloblastoma with Extensive } \\
\text { Nodularity (WHO Grade IV); } \\
\text { Anaplastic Medulloblastoma } \\
\text { (WHO Grade IV). }\end{array}$ & Neuron & $\begin{array}{c}\text { p53 mutation } \\
\text { TRKC, ERBB2, FSTL5 } \\
\text { overexpression } \\
\text { PTCH1, CTNNB1 mutation } \\
\text { MYC amplification } \\
\text { DDX3X mutation }\end{array}$ & $\begin{array}{l}\text { Medulloblastomas are } \\
\text { tumors of the cerebellum. } \\
\text { Main symptoms are } \\
\text { headache, morning } \\
\text { vomiting, ataxia. }\end{array}$ & [70-78] \\
\hline
\end{tabular}

${ }^{1}$ WHO, World Health Organization.

Current diagnostic approaches are based on imaging methods with subsequent histological examination of a biopsy. However, these approaches are limited by tumor localization and heterogeneity. Treatment choices can vary depending on tumor type and location, malignancy potential and patient's conditions, and include surgery, radiotherapy, chemotherapy, or a combination. Complete safe surgical resection, followed by radio/chemotherapy, represents the most common initial treatment for many primary brain tumors. The main aims are to achieve an accurate histological diagnosis, define the tumor's molecular genotype, reduce the mass effect and tumor burden, improve patient's quality of life, and prolong survival time $[2,79,80]$.

Despite efforts to develop new therapeutic strategies, including surgical procedures, and radio-, chemo-, and immunotherapies, brain tumors continue to be a substantial source of morbidity and mortality worldwide, a situation compounded by late diagnosis and the development of resistance to anticancer agents [81-83].

For this reason, repeated attempts have been made over the last few years to identify specific biomarkers that could be detected/measured using noninvasive methods and that would allow early diagnosis and disease monitoring, including controlling the response to treatment [84].

Among the diagnostic and prognostic markers currently under investigation, miRNAs and molecular chaperones released by EVs hold promise, considering their roles in physiology and pathology. For example, they are implicated in the regulation of the cellular proteome at transcriptional and post-transcriptional levels. Thus, it is likely that cancer cells may use miRNAs and chaperones by delivering them to other cells and influence them in ways favoring tumorigenesis.

\section{1. miRNAs in Brain Tumors}

MicroRNAs are short noncoding single stranded RNA (ssRNA) molecules, 19-25 nucleotides long, which regulate the expression of target genes post-transcriptionally by affecting either the stability or the translation of their mRNA [85].

The biogenesis of miRNAs consists of two highly regulated cleavage events [86]. The first one, occurring within the nucleus, generates a long hairpin-shaped RNA molecule called pre-miRNA [87-92] which is exported to the cytoplasm, in which the second step occurs, producing a shorter double stranded RNA [93-97]. One of the strands, the star $\left(^{*}\right)$ strand or passenger strand, is degraded. The other strand (the guide strand or mature miRNA) forms the miRNA-induced silencing complex (miRISC) that specifically recognizes a target mRNA, and downregulates gene expression by repression of translation or by mRNA cleavage [98-104]. However, in recent years it became clear that the passenger strand may not be degraded and could act as miRNA. Thus, according to a more recent nomenclature proposed by the miRBase registry, the two miRNA strands produced after the second cleavage are referred to as predominant product (indicated without ${ }^{*}$ ) and the strand from the opposite arm of the precursor 
(indicated with *). When the data are not sufficient to determine which sequence is predominant, the strands are indicated as $5 p$, i.e., present in the forward $\left(5^{\prime}-3^{\prime}\right)$ position, and $3 p$, i.e., located in the reverse $\left(3^{\prime}-5^{\prime}\right)$ position [105].

Since their discovery over 30 years ago in the nematode Caenorhabditis elegans [106,107], a myriad of new miRNAs have been identified and annotated in the miRbase registry, and their number continuously increases thanks to the development of new high-throughput sequencing technologies and computational and bioinformatics prediction methods, which facilitate identification of miRNAs targets and their biological functions [108-114].

Currently, in humans over 2000 miRNAs have been annotated and validated, which regulate the vast majority of protein encoding genes, and thus most if not all biological events [115-121]. For this reason, any alteration of a miRNA normal expression profile was often related to pathology, including cancer as firstly suggested by the depletion or downregulation of miR-15a and miR-16a genes in the majority of B-cell chronic lymphocytic leukemia [122]. Typically, when miRNAs expression is amplified in cancer cells, they function as oncogenes and promote cancer development by negatively regulating tumor suppressor genes and/or genes that control cell differentiation or apoptosis. Conversely, when downregulated, miRNAs act as tumor suppressors and may inhibit tumorigenesis by regulating oncogenes and/or genes that control cell differentiation or apoptosis $[123,124]$. There are several mechanisms inducing miRNAs dysregulation in cancer, such as (i) miRNAs genes amplification or deletion [122,125]; (ii) abnormal transcriptional regulation of miRNA genes [126,127]; (iii) epigenetic alterations, such as aberrant DNA methylation and histone acetylation of miRNAs genes, which, in turn, affect miRNAs levels [128,129]; and (iv) defects in miRNAs biogenesis and maturation pathways, which can alter their expression [130,131].

MicroRNAs with expression levels different in the tumoral tissues as compared with the normal tissue counterparts were identified for several tumor types, for instance glioblastoma [132-134].

More than 70 percent of all brain tumors are gliomas that are classified according to the type of the glial cell involved, and include astrocytoma (astrocytoma, anaplastic astrocytoma, and glioblastoma), ependymomas (anaplastic ependymoma, myxopapillary ependymoma, and subependymoma), and oligodendrogliomas (oligodendroglioma, anaplastic oligodendroglioma, and anaplastic oligoastrocytoma) (Table 2). Microarray studies on miRNAs have shown significant changes of their expression profile in gliomas, both in children and in adults [135,136] (Table 2).

Compared to normal brain tissues, miRNA-155 (miR-155) was found overexpressed in glioma tissues, and its overexpression was associated with poor overall survival rates, suggesting that monitoring its expression levels could be a way to assess prognosis [137]. The positive correlation between miR-155 expression level and glioma malignancy was further established by in vitro and in vivo studies [138]. In vitro, miR-155 promoted tumor cells proliferation, invasion, and migration by downregulating two components of the mitogen-activated protein kinase (MAPK) signaling pathway and, in turn, enhancing secretion of matrix metalloproteinases 2 (MMP2) and MMP9 [138]. Moreover, it competed with miR-185 to induce ANXA2 (annexin A2), which exhibited oncogenic functions in glioblastoma multiforme (GBM) [139]. In vivo studies showed that miR-155 facilitated the progression of glioblastoma and confers drug resistance by modulating Six1 expression [140]. These results confirm the role of miR-155 as oncomiR and suggest its potential use as biomarker and as anticancer drug target. In fact, its knockdown sensitized glioma cells to temozolomide, a common anticancer drug, through the induction of MAPK13, MAPK14, and Six1, and mediated oxidative stress and apoptosis $[138,140]$ (Table 2).

The other two miRNAs proposed as oncomiRs, and potential prognostic biomarkers, are miR-221 and miR-222, whose high levels of expression are positively correlated with glioma aggressiveness and poor prognosis [141,142]. Among miR-221 and miR-222 targets that are involved in these protumorigenic effects are the tissue inhibitor of metalloproteinase (TIMP3), which is downregulated concomitantly with miR-221 and miR-222 overexpression, promoting glioma cell invasion [141], and the Akt pathway, which is activated, promoting cancer cell proliferation [143]. Conversely, cosuppression of miR-221 and miR-222 suppresses human glioma-cell growth and proliferation by a mechanism involving the 
upregulation of the cell cycle inhibitor p27Kip1 both in vitro and in vivo [144]. Moreover, as reported for the oncomiR-155, downregulation of miR-221 and miR222 sensitizes glioma cells to temozolomide by increasing the expression of proapoptotic factors [145] (Table 2).

There are also several examples of miRNAs considered tumor suppressors of malignant gliomas. Low plasma level of miR-185 is a signature of a glioma that correlates with poor survival [146]. Its inhibition after miR-155 overexpression in GBM promoted ANXA2 expression and tumor growth and progression [139]. Similarly, serum miR-205 expression was significantly lower in patients with glioma than in healthy controls, as well as in other brain tumor cohorts, and its serum level appeared inversely correlated with pathological grades and overall survival, since patients with glioma at an advanced pathological grade (grade III or IV) and a higher miR-205 serum level had a longer overall survival than those with a lower miR-205 serum concentration [147]. Thus, miR-185 and miR-205 were identified as tumor suppressors and were proposed as biomarkers with predictive prognostic potential to be used with noninvasive tools for monitoring cancer progression and response to treatment [146-149] (Table 2).

Glioblastoma multiforme (WHO grade IV astrocytoma) is characterized by poorly differentiated glial cells with polymorphism, nuclear atypia, and high mitotic activity, and is the most common malignant primary brain tumor, with an incidence of 3.19 cases per 100,000 person/year and a remarkably poor prognosis due to the still limited therapeutic options [150]. Therefore, the identification of new diagnostic and prognostic biomarkers is necessary to develop novel and personalized therapeutic treatments. Also, in this case, great interest was elicited by miRNAs, which often show an altered expression level in GMB patients compared to healthy controls, as already discussed for miR-155 and miR-185. It was observed that the serum level of miR-203 is decreased in GBM patients compared with low grade glioma (LGG) patients and healthy controls, and it positively correlates with poor overall survival [151]. These results confirm the tumor-suppressor activity of miR-203 in GMB, whose low expression level in two human GBM cell lines was previously shown to induce their epithelial-mesenchymal transition and confer them chemoresistance [152] (Table 2).

Similarly, miR-605 has a reduced expression level in GMB tissues and cell lines, and this was correlated with patients' poor survival [153]. Conversely, increased levels of miR-605 inhibited cancer cell proliferation and growth in vitro and in vivo, by directly targeting SOX9 (SRY-box 9) and by inhibiting the activation of the PI3K (phosphatidylinositol 3-kinase)/Akt (protein kinase B) pathway [153] (Table 2).

Compared to GBM, much less is known about circulating miRNAs as useful indicators for diagnosis and prognosis of meningiomas. In addition, for these tumors, miRNAs have been identified that act as oncogenes or tumor suppressors. For instance, miR-200a has been implicated in the pathogenesis of meningiomas and was found downregulated in sporadic benign human meningioma tumors (WHO grade I), compared to the arachnoid tissues from which these tumors arise [154]. This miRNA functions as a potential tumor suppressor since its upregulation inhibits $\mathrm{Wnt} / \beta$-catenin signaling, involved in cell proliferation, through two complementary mechanisms: a) direct targeting of the $\beta$-catenin mRNA, which reduces the levels of $\beta$-catenin, acting as the main activator of the Wnt signaling; and b) targeting the mRNAs for ZEB1 (Zinc Finger E-Box Binding Homeobox 1) and SIP1 (Smad Interacting Protein $1)$, which negatively regulate the expression of the E-cadherin gene, with a consequent upregulation of E-cadherin levels and sequestration of $\beta$-catenin [154]. Another mir-200a target is the nonmuscle myosin heavy chain Ilb (NMHCIIb), involved in regulation of cells motility. NMHCIlb downregulation concomitantly with miR-200a overexpression in malignant meningioma cells significantly reduced the rate of cancer cells migration, and thus tumor invasiveness [155].

The expression level of miR-145 appears significantly reduced in atypical and anaplastic tumors as compared with benign meningiomas [156]. In vitro, the overexpression of miR-145 reduced meningioma cells proliferation and motility, thanks to the associated downregulation of collagen type $\mathrm{V}$ alpha (COL5A1) and induced apoptotic cell death [156]. These effects translated into a decreased growth of an orthotopic tumor in a nude mice model, with reduction in tumor cell infiltration upon overexpression of miR-145 [156] (Table 2). 
The microRNA miR-335 is overexpressed in meningiomas and acts as an oncomiR. It has been shown that elevated levels of miR-335 in vitro increased tumor cell growth by directly targeting the signaling pathway of the tumor suppressor $\mathrm{Rb} 1$, whereas reduction of the miR-335 levels had the opposite effect on tumor growth and progression, leading to cell cycle arrest in the G0/G1 phase [157].

The oncogenic role of miR-335 was observed also in astrocytoma, a type of glioma deriving from astrocytes or astroglial precursors; it was overexpressed in astrocytoma cells, promoting their growth and invasiveness by targeting the tumor suppressor disheveled-associated activator of morphogenesis 1 (Daam1), a member of the formin protein family acting downstream of Wnt signaling, and responsible for the regulation of cell polarization, migration, proliferation, and tissue morphogenesis during embryonic development [158]. On the contrary, miR-335 inhibition suppressed growth and induced apoptosis of astrocytoma cells in vitro and in vivo, suggesting its potential use as therapeutic target [158] (Table 2).

The microRNA miR-224 level was found higher in meningioma tissues compared to normal brain and was positively correlated with advanced pathological grade [159]. miR-224 could be a promising therapeutic target for treating malignant meningiomas, since its downregulation in vitro suppressed cell growth and increased apoptosis through the activation of the ERG2-BAK-induced apoptosis pathway [159] (Table 2). Six miRNAs (miR-106a-5p, miR-219-5p, miR-375, miR-409-3p miR-197, and miR-224) were identified in serum from patients with meningioma [160]. The serum levels of miR-106a-5p, miR-219-5p, miR-375, and miR-409-3p were increased in meningioma patients compared to healthy controls and decrease after tumor removal. On the contrary, the serum levels of miR-197 and miR-224 were markedly decreased in meningioma patients but significantly increased in the postoperative samples of the same patients. Therefore, the use of this panel of miRNAs was suggested as potentially useful for the diagnosis and the evaluation of clinical outcomes during management of meningioma patients [160] (Table 2).

Similarly, very recently the use of miRNAs profiling was proposed as novel tool to predict meningiomas recurrence, and improve patients' clinical management [161].

MicroRNA profiling in brain tumor biology has been conducted considering not only the miRNAs expressed in malignant tissues and in blood from patients, but also the miRNAs released in the cerebrospinal fluid (CSF). CSF is considered the ideal source of nervous tissue-specific miRNAs to use as diagnostic biomarkers for brain tumors, since it is in direct contact with the entire central nervous system, and has the advantage of containing fewer miRNAs than blood plasma or serum, which, flowing throughout the body, collect miRNAs generated by all tissues [162-167]. Recently, a screening was conducted, using CSF samples from patients with glioblastoma, low-grade glioma, meningioma, and brain metastasis, and from nontumor patients as controls, with the aim of identifying specific CSF miRNA patterns that could differentiate brain tumors from one another [166]. CSF miRNA signatures were identified for all the cancer types studied, which revealed the potential of CSF miRNAs for diagnosis of brain tumors, especially in cases with borderline or uncertain imaging results [166] (Figure 1).

Table 2. MicroRNAs in brain tumors.

\begin{tabular}{|c|c|c|c|c|c|}
\hline \multirow{2}{*}{ Tumor } & \multirow{2}{*}{ miRNA } & \multirow{2}{*}{ Function } & \multicolumn{2}{|r|}{ Quantity } & \multirow{2}{*}{ Ref. } \\
\hline & & & Level & Tissue/Cell & \\
\hline \multirow{7}{*}{ Glioma } & & & Increased & GBM cells and derived EVs ${ }^{1}$ & [168-174] \\
\hline & miR-21 & OncomiR & Increased & $\begin{array}{c}\text { Blood; GBM cells } \\
\text { derived EVs }\end{array}$ & [175] \\
\hline & miR-148a & OncomiR & Increased & $\begin{array}{l}\text { Glioma tissues; glioma cell } \\
\text { line; GBM specimens } \\
\text { and cell line }\end{array}$ & [137-140] \\
\hline & miR-155 & OncomiR & Increased & Blood; Glioma cell line & [141-145] \\
\hline & $\operatorname{miR}-221 / 222$ & OncomiR & Increased & Blood & [176] \\
\hline & miR-301a & OncomiR & Increased & GBM patient's serum & [177] \\
\hline & $\begin{array}{l}\text { miR-222, miR-124-3p, } \\
\text { miR-221, miR-320, } \\
\text { miR-574-3p, } \\
\text { and miR-301a }\end{array}$ & $\begin{array}{l}\text { Positive diagnostic } \\
\text { biomarkers }\end{array}$ & Increased & Astrocytoma cells & [158] \\
\hline
\end{tabular}


Table 2. Cont

\begin{tabular}{|c|c|c|c|c|c|}
\hline \multirow{2}{*}{ Tumor } & \multirow{2}{*}{ miRNA } & \multirow{2}{*}{ Function } & \multicolumn{2}{|r|}{ Quantity } & \multirow{2}{*}{ Ref. } \\
\hline & & & Level & Tissue/Cell & \\
\hline \multirow{10}{*}{ Glioma } & miR-335 & OncomiR & Increased & GBM cells and derived EVs & [168] \\
\hline & $\operatorname{miR}-451$ & OncomiR & $\begin{array}{l}\text { Increased in cells } \\
\text { and released in EVs }\end{array}$ & GBM cells and derived EVs & [178] \\
\hline & $\operatorname{miR}-1238$ & OncomiR & Low levels in cells & GBM cells and derived EVs & [179] \\
\hline & miR-1 & Tumor suppressor & Released in EVs & GBM cells derived EVs & [180] \\
\hline & miR-151a & Tumor suppressor & Low levels & $\begin{array}{l}\text { Blood; GBM specimens } \\
\text { and cell line }\end{array}$ & {$[139,146,149]$} \\
\hline & miR-185 & Tumor suppressor & Decreased & GBM cell lines and blood & {$[151,152]$} \\
\hline & miR-203 & Tumor suppressor & Low levels & Blood & {$[147,148]$} \\
\hline & miR-205 & Tumor suppressor & Low levels & GBM tissues and cell lines & {$[181,182]$} \\
\hline & $\operatorname{miR}-454$ & Tumor suppressor & Low levels & GMB tissues and cell lines & [153] \\
\hline & miR-605 & Tumor suppressor & Increased & Meningioma tissues & [159] \\
\hline \multirow{8}{*}{ Meningioma } & $\operatorname{miR}-224$ & OncomiR & Increased & $\begin{array}{l}\text { Meningioma tissues; } \\
\text { meningioma cell }\end{array}$ & [157] \\
\hline & $\operatorname{miR}-335$ & OncomiR & Low levels & $\begin{array}{l}\text { Atypical and anaplastic } \\
\text { meningiomas; } \\
\text { meningioma cell }\end{array}$ & [156] \\
\hline & miR-145 & Tumor suppressor & Low levels & Benign meningioma tissue & {$[154,155]$} \\
\hline & $\operatorname{miR}-20 \mathrm{~A}_{3}$ & Tumor suppressor & Increased & Malignant meningioma cells & {$[154,155]$} \\
\hline & mik-200a & Tumor suppressor & High levels & Blood & [160] \\
\hline & $\begin{array}{l}\text { miR-106a-5p, miR-219-5p, } \\
\text { miR-375, and miR-409-3p }\end{array}$ & $\begin{array}{c}\text { Diagnostic and prognostic } \\
\text { biomarkers }\end{array}$ & Low levels & Blood & [160] \\
\hline & miR-197 and miR-224 & $\begin{array}{c}\text { Diagnostic and prognostic } \\
\text { biomarkers }\end{array}$ & $\begin{array}{l}\text { Increased } \\
\text { following } \\
\text { recurrence }\end{array}$ & Tumor samples & [161] \\
\hline & $\begin{array}{l}\text { miR-15a-5p, miR-146a-5p, } \\
\text { and miR-331-3p }\end{array}$ & Prognostic biomarkers & & & {$[161]$} \\
\hline
\end{tabular}

${ }^{1}$ GBM, glioblastoma multiforme.

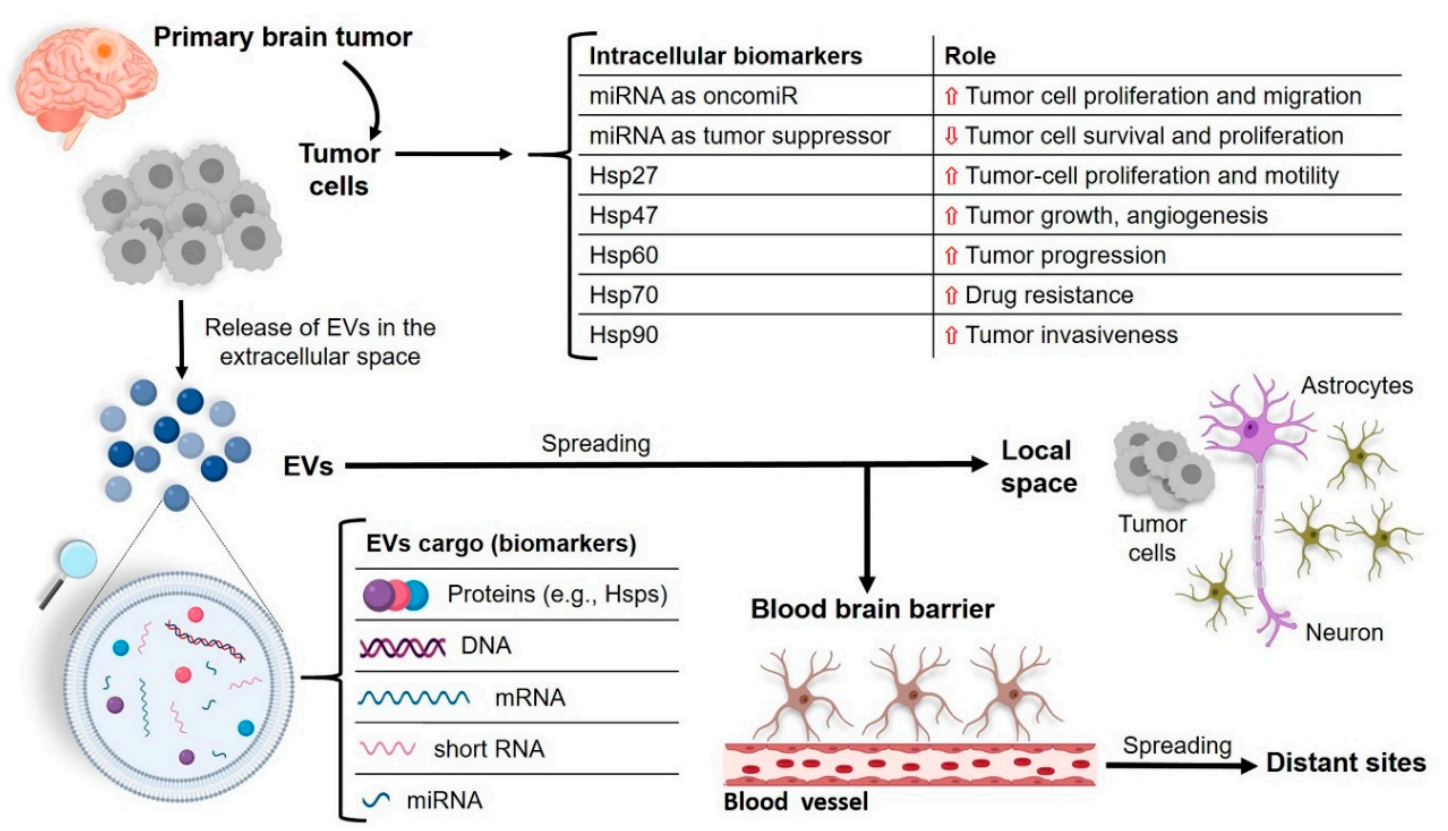

Figure 1. Schematics of the production and migration of extracellular vesicles (EVs) released by brain tumors and their local and distant cell targets (top half of the figure) with the components of their cargo discussed in this article (bottom half).

\subsection{Molecular Chaperones in Brain Tumors}

Molecular chaperones are the main components of the chaperoning (chaperone) system (CS) of an organism, which is also constituted of co-chaperones, chaperone cofactors and chaperone receptors and interactors, forming different functional networks $[183,184]$. Some chaperones are called Hsp (from heat shock protein), since they increase in response to heat shock and other stressors [185-188]. Although not all chaperones are Hsps and vice versa not all Hsps are chaperones, both terms have been 
used indistinctly for years, as if they were true synonyms. This unfortunate confusion is practically impossible to eradicate from the literature and continues to thrive. Therefore, we use the terms chaperone and Hsp interchangeably in this work.

The canonical functions of chaperones pertain to protein homeostasis and quality control [189-198]. However, chaperones have also noncanonical functions unrelated to the maintenance of protein homeostasis, including participation in immune and inflammatory reactions [12,199-201].

The CS interacts with the immune system and when malfunctional, it becomes a pathogenic factor in autoimmune and inflammatory diseases. The diseases in which components of the chaperone system play an etiological-pathogenic role are the chaperonopathies [202].

As for most diseases, chaperonopathies can be genetic or acquired, with the former being the result of a gene variant, e.g., mutation, while the acquired chaperonopathies are characterized by structural and functional abnormalities in the chaperone protein, but its gene is normal. In addition, chaperonopathies can be classified according to its main feature as by defect, by excess, and by mistake [203]. Typically, chaperonopathies associated with cancer are by mistake, namely the pathogenic chaperone helps the tumor cell rather than defend the human host against it. Since chaperones are classically considered cytoprotective and guardians of protein homeostasis, their helping malignant cells to grow, proliferate, and disseminate appear as mistaken activities, so to speak. This concept has played a key role in alerting physicians and pathologists to the fact that chaperones may be determinant pathogenic factors and should be looked upon as tumor biomarkers and targets for treatment, with negative chaperonotherapy being the modality of choice most often, which consists of inhibiting, blocking, or eliminating the "mistaken" chaperone.

Molecular chaperones can confer resistance against chemo- and radiotherapies, and support glial tumor growth and invasion, i.e., the typical role of "mistaken" chaperones that characterize the chaperonopathies by mistake, underpinning carcinogenic mechanisms in certain types of tumors [13,204-208] (Table 3).

A positive correlation between Hsp27 expression level and the growth rate of different types of high-grade astrocytoma, including glioblastoma, has been reported, suggesting its involvement in promoting tumor growth $[209,210]$. Hsp27 is an important regulator of F-actin polymerization and it was shown that p38MAPK activation, followed by Hsp27 phosphorylation, was required for Phorbol 12-myristate 13-acetate (PMA)-induced migration of glioblastoma cells, suggesting that this chaperone is a potential target of negative chaperonotherapy to inhibit cancer invasion and progression [211]. This hypothesis was further supported by findings showing that Hsp27 downregulation synergizes the anticancer effects of different drugs and treatments, reducing GBM cell proliferation and promoting caspase 3-mediated apoptosis [212-214].

Another Hsp involved in glioblastoma tumorigenesis is Hsp47. Hsp47 was found overexpressed in glioma tissues and cell lines and associated with glioma tumor grade [215]. Moreover, its expression level was positively correlated with tumor vascularization, since its silencing consistently decreased VEGF expression in glioma cells, and reduced glioma vasculature [215]. Hsp47 knockdown also inhibited glioma cell growth, migration, and invasion in vitro and in vivo [216]. Contrarily, in vivo Hsp47 overexpression promoted primary glioma cell tumor formation and stemlike properties maintenance, as well as tumor invasion and angiogenesis, thanks to the upregulation of extracellular matrix related genes, such as CD44, LAMC1m COL4A2, ITGB1, FN1, and MMP9, through the TGF- $\beta$ pathway [217]. These data indicate a key role of $\mathrm{Hsp} 47$ in glioma angiogenesis, suggesting its potential use as therapeutic target to treat glioma tumors (Table 3).

In addition, the involvement of the mitochondrial chaperonin Hsp60 in glioblastoma tumorigenesis and progression has been studied. The Hsp60 expression level was found higher in glioblastoma patients and cell lines, with an antiapoptotic and a prosurvival role [218,219]. Hsp60 through its interaction with cyclophilin D, Hsp90, and other cofactors, modulates tumor growth and prevents apoptosis in vivo [218]. Moreover, the chaperonin downregulation in glioblastoma cells leads to epithelial-mesenchymal transition and increases production of reactive oxygen species (ROS), ultimately suppressing cell growth and proliferation through the ROS/AMPK/mTOR pathway [219]. The protumorigenic role of Hsp60 was 
suggested also by immunohistochemical analysis on a subset of human brain neoplasms by comparing the levels of Hsp60 and Hsp70, another Hsp commonly implicated in carcinogenesis [220-222]. The results showed a significant difference between Hsp60 and Hsp70 levels in neuroepithelial tumors, while levels of both molecules did not differ among each other in meningeal neoplasms. It was suggested that Hsp60 is not increased by a passive phenomenon, but may play an active role in tumor progression, although other studies are needed to fully understand this issue $[220,223,224]$.

$\mathrm{Hsp70}$ is another chaperone that is thought to play a role in carcinogenesis, since it was found abundantly expressed in malignant cells, and with different roles [225]. For instance, the cytosolic, membrane-bound, and extracellular forms of Hsp70 are augmented in primary glioblastomas [226], and its increase was associated with increased proliferation, migration, and invasion rates, as well as with acquisition of radio resistance by human glioblastoma cell lines $[227,228]$. It has been shown that Hsp70 promotes survival of C6 and U87 glioma cells, by protecting ATF5 from proteasome and caspase-dependent proteolytic degradation [229]. Moreover, in a rat model of GBM (C6 cells), Hsp70 elicited cytoprotective activity and rescued glioblastoma cells from oxidative stress and death by sequestrating the aggregation-prone GAPDH, which is usually responsible for pathogenic aggregation of proteins after cell exposure to oxidative stress. The protective power of the chaperone could be abolished by specific inhibitors of Hsp70 expression [230] (Table 3).

Another Hsp with a protumorigenic role in glioma is Hsp90, which through different signaling pathways, promotes cancer cell motility and invasion [231-234]. In addition to migration, Hsp90 regulates other protumorigenic processes in GBM cells, such as cell-survival mechanisms and apoptosis. Consequently, a combined treatment with Hsp90 and PI-3 kinase inhibitors has been shown to increase the apoptotic death of GBM cells, likely by disrupting AKT signaling and promoting G2/M arrest [235]. In agreement with these results, several works demonstrated the efficacy of Hsp90 inhibitors in counteracting malignant gliomas, proposing their use, alone or in combination with other traditional anticancer drugs, as potential therapeutic agents in gliomas treatment-all examples of negative chaperonotherapy [208,236-238] (Table 3).

Compared to malignant gliomas, less is known about the role played by Hsps in other brain tumors. Two different studies investigated different Hsps on paraffin-embedded sections from medulloblastoma patients using immunohistochemistry and found substantial amounts of them [239,240]. However, these data are still preliminary and further studies, involving a larger series of patients, are necessary to clarify the relationship of Hsps with tumor aggressiveness and prognosis [239,240] (Figure 1).

Table 3. Reported roles of Hsp27, Hsp47, Hsp60, Hsp70, and Hsp90 in gliomas.

\begin{tabular}{|c|c|c|}
\hline Chaperone/Hsp & Role in Gliomas & Ref. \\
\hline Hsp27 & Promotes tumor growth, and cancer-cell proliferation and motility & [209-214] \\
\hline Hsp47 & Promotes tumor growth, invasiveness, and angiogenesis & [215-217] \\
\hline Hsp60 & $\begin{array}{l}\text { Promotes tumor progression by enhancing cancer-cell proliferation, preventing } \\
\text { apoptosis, and inhibiting the antitumor immune response }\end{array}$ & [218-220] \\
\hline Hsp70 & $\begin{array}{l}\text { Promotes cancer cell proliferation, migration, and invasion, and protects cancer } \\
\text { cells from apoptosis and anticancer drugs }\end{array}$ & [227-230] \\
\hline Hsp90 & Promotes cancer-cell motility, tumor invasiveness, and drug resistance & [231-235] \\
\hline ССТ6 & Promotes GBM cell invasion and has a negative association with patient survival ${ }^{1}$ & [241] \\
\hline
\end{tabular}

\section{The Release of miRNAs and Chaperones through EVs as Molecular Signaling and Source of Biomarkers}

Intercellular communication between tumor cells and their neighboring structures, including other cells, is vital for cancer growth and progression, and EVs are key elements in this crosstalk. However, the mechanisms involved are still poorly understood, which stands in the way of progress in cancer treatment. The involvement of brain tumor-derived EVs in the modulation of the tumor microenvironment has been suggested by studies that revealed in those vesicles functionally active molecules that can play a role in cancer progression. 
The release of Hsps inside vesicles has been reported for different brain tumor cell lines [242]. Moreover, it has been found that Hsp27, Hsp70, and Hsp90 can also be present on the surface of brain tumor-derived EVs [243,244], which indicate their potential as tumor biomarkers [245,246]. However, although molecular chaperones have been described as key players in brain tumor biology, in the current literature there are still very few data about the possible role of extracellular Hsps in these tumors. On the contrary, the role of miRNAs carried by EVs released by brain tumor cells is currently under active investigation and debate. MicroRNAs in EVs are abundant by comparison with other cargo molecules [247] and their expression patterns reflect their source, thus providing information about their cells of origin [248]. For instance, gliomas secrete EVs that transport receptors and signaling molecules for oncogenes $[16,249,250]$. The EV-mediated transfer of miRNAs appears to be a way for the tumor to communicate with distinct sets of surrounding nontumor cells, including neurons and glial and vascular cells, which are thus reprogrammed to modify the tumor microenvironment to make it suitable to tumor growth and dissemination [251]. For example, it has been shown that glioma-derived EV saltered synaptic activity in neurons, contributing to tumor growth [251]. In addition, several studies have pinpointed the specific role of certain vesicular miRNAs on target cells, which in essence consisted in mediating the aggressive properties of gliomas [178-180,252]. The microRNAs miR-451 and miR-21 are present at very high levels in the EVs produced by primary GBM cells, and are uptaken by microglia, which is followed by a phenotype change of the recipient cell accompanied by upregulation of cytokines, chemokines, and matrix metallopeptidases (MMP), all of which promote growth and invasion of GBM cells while lessening of the immune response [168]. MiR-21 transferred by GBM-EVs to microglia regulates the expression of the Btg2 gene, involved in the control of cellular proliferation and differentiation [169]. The dysregulation of c-Myc and Btg2 attests that the GBM-EVs have a functional activity on neighboring target cells. Several studies suggest the oncogenic effect of miR-21, whose overexpression occurring in many tumor types favors the establishment of tumor-permissive pathways in glioblastoma $[170,171]$. It has been observed that malignant brain tumor-derived EVs support neoangiogenesis through miR-21/VEGF signaling [172].

MicroRNAs can cross the blood-brain barrier (BBB) and reach far target sites through the circulation. For instance, the vesicular miR-21 has been identified in the blood [250] and CSF [173,174], suggesting that these EVs carrying miRNAs could have diagnostic and prognostic usefulness.

Both miR-105 [253] and miR-181c [254] have the ability to disrupt the blood-brain barrier and function as pro-oncogenes by downregulating tumor suppressor genes, and thereby favor invasiveness and metastasization. It has also been reported that miR-148a delivered by EVs promotes glioma-cell proliferation and metastasis via targeting CADM1 to activate the STAT3 pathway [175].

The content in miRNAs within EVs released by a tumor can vary depending on the stage of tumor progression, thus providing key diagnostic indicators, which is particularly convenient when it is possible to isolate the EVs from biological fluids such as plasma [163]. For instance, miR-222, miR-124-3p, miR-221, miR-320, miR-574-3p, and miR-301a were found to be increased in EVs derived from serum of high-grade glioma patients $[176,177]$ and their distinctive quantitative patterns allowed for distinguishing between tumoral and control samples [177].

The pathogenic role of some miRNAs depends on their tissue localization. For instance, miR-454 may act as an oncogene in gastric cancer [255], but is a tumor suppressor in gliomas [181]. The microRNA miR-454 is elevated in EVs from preoperative sera when compared with its levels after surgery, indicating that cancer cells can differentially secrete specific miRNAs into the circulation in EVs, which support the idea that these vesicles and their contents have potential as useful biomarkers accessible with minimally invasive procedures [182].

Despite their fundamental role in cell homeostasis and the knowledge that molecular chaperones are differentially expressed in cancer, little is known about the secretion of these proteins by brain tumors via EVs. The stress response of tumor cells, included those of brain tumors, consists of the overexpression of Hsps and their release in the extracellular environment also by EVs. However, little is known on the role of molecular chaperones in the brain tumor microenvironment; one working 
hypothesis postulates that the release of chaperones via EVs could be a defense mechanism from injury $[242,256]$.

CCT6A, a subunit of the molecular chaperone CCT (Chaperonin-containing Tcp-1) is present in EVs from glioma cells derived from surgical specimens [241]. Secretion of CCT6A via EVs could be linked to GBM cell invasion and has a negative association with patient survival [241] (Figure 1).

After their release in the extracellular space, EVs can either perform a local autocrine/paracrine signalling, targeting other nearby tumor cells and nervous-system cells (neurons and astrocytes), or cross the blood-brain barrier and reach distant cells through the systemic circulation. In both cases, EVs release their cargo into the cytoplasm of recipient cells by fusing with the target-cell membrane. At this point, the delivered molecules can mediate many physiological and pathological processes. EVs cargo reflects the characteristics of the cells from which they originate. Therefore, it is likely that both miRNAs and Hsps normally produced by tumor cells may be selected for the sorting into the released EVs and affect the tumor microenvironment and other distant tissues. As indicated in the bracket at the top right half of Figure 1, miRNAs may act either as oncomiR, favoring tumor cells proliferation and migration, or as tumor suppressor, by inhibiting cancer cells survival and proliferation. In both cases, the role is mediated by the post-transcriptional regulation of factors involved in the control of the cell life cycle and is correlated to the level of the pertinent miRNA. On the contrary, Hsps act mainly as protumorigenic factors (i.e., chaperonopathies by mistake), since Hsps promote cancer cell proliferation and motility (Hsp27); tumor growth, invasiveness, and angiogenesis (Hsp47); prevent tumor cell apoptosis and inhibit antitumor immune response (Hsp60); and confer resistance to anticancer treatment (Hsp70 and Hsp90).

\section{Conclusions and Perspectives}

Tumor-derived EVs with their miRNA and molecular chaperone contents have potential applications in medicine for diagnostic purposes, for monitoring patients, and for designing and implementing novel therapeutic procedures. Methods for isolating EVs and for characterizing their cargo have been developed over the last few years and interest has increased in their possible role as intercellular messengers. Tumor-derived EVs are considered a potential source of biomarkers, reflecting the status and metabolism of the cells from which they originate. Because of this and of their availability via minimally invasive sampling procedures, EVs have a promising future in brain tumor management, including early diagnosis and patient follow up. It is hoped that as knowledge about these vesicles and their physiological and pathogenic roles progresses, mechanistic insights will be gained that will pave the way for developing novel treatment strategies and drugs. Here, we have discussed two components of the EVs cargo, miRNAs and molecular chaperones, the key functions of which in carcinogenesis and in the fight of the organism against malignancies, and vice versa, are becoming increasingly clear. Therefore, measurement and characterization of miRNA and chaperones in EVs from brain tumors in liquid biopsies are promising endeavors in research and medical practice, particularly in neurosurgery. Furthermore, learning about EVs from brain tumors and their migrations within the brain and the rest of the body will tell whether these vesicles have potential as vectors for delivering anticancer drugs to specific cell targets.

The efficacy of EV-carried noncoding RNAs has been examined in neurodegenerative diseases [257] and in tumors [258]. Systemically administered engineered EVs, targeting the transferrin receptor, were found to bind glioblastoma cells and enhance the action of the antisense miRNA oligonucleotide produced to inhibit endogenous miR-21 [259].

Natural or artificially constructed EVs carrying chaperones have been tested for their ability to enhance the antitumoral immune response. For example, Hsp70 contained in EVs from dendritic cells activated T lymphocytes toward becoming glioma-specialized cytotoxic T lymphocytes [260]. Chaperone-enriched EVs have been tested in glioma immunotherapy in an in vivo model and have shown strong induction of the CD4+ and CD8+ T cell activity and enhancement of T cell infiltration in intracranial glioma tissues, causing inhibition of tumor growth [261]. 
Other advances in EVs application in tumor therapy are their use as target-specific carriers to deliver tumor suppressor miRNAs or miRNA-mimic molecules. Some miRNA-mimic molecules have the capability of targeting and reducing the protumoral effect mediated by Hsps. This has been demonstrated in a triple-negative breast cancer model, in which miR-134-enriched EVs reduced the levels of Hsp90, a chaperone that favors the survival of cancer cells by stabilizing oncogenic proteins [262]. This treatment resulted in reduced cell migration and invasion, and enhanced sensitivity to anti-Hsp90 drugs in breast cancer cells [262]. Delivery of specific miRNAs or anti-miRNA molecules played important roles in the modulation of the expression of Hsps, with therapeutic effects in cancer [263]. In the vascular endothelial cells of gliomas, miR-144 targeted directly Heat Shock Factor 2, which regulates Hsps expression, modifying the permeability of the blood-tumor barrier, which opens a potential new way in glioma treatment centered on the regulation of Hsp expression by Heat Shock Factors [264].

These findings point the way for future research aiming at finding and producing miRNAs and miRNA-mimic molecules targeting Hsps in brain tumors. Thus, EVs and miRNA and chaperones in their cargo have potential not only in diagnosis and patient monitoring but also for brain cancer treatment.

Author Contributions: Conceptualization, A.M.V., R.S., C.C., E.C.d.M., F.B., A.J.L.M., and C.C.B.; original draft preparation, A.M.V., R.S., G.V., A.M.G., and C.C.B.; supervision, F.B., A.J.L.M., and C.C.B. All authors have read and agreed to the published version of the manuscript.

Funding: This work was funded in part by the Italian National Operational Programme (PON) «Imprese e Competitività» 2014-2020 FESR, grant awarded by the Italian Ministry of Economic Development to the project titled «Gestione di un servizio integrato multicentrico di diagnostica e terapia personalizzata in oncologia» (Project code: F/090012/01-02/X36). A.J.L.M and E.C.d.M. were partially supported by IMET and IEMEST. This is IMET contribution number IMET 20-019.

Conflicts of Interest: The authors declare no conflict of interest.

\section{References}

1. Bray, F.; Ferlay, J.; Soerjomataram, I.; Siegel, R.L.; Torre, L.A.; Jemal, A. Global cancer statistics 2018: GLOBOCAN estimates of incidence and mortality worldwide for 36 cancers in 185 countries. CA Cancer J. Clin. 2018, 68, 394-424. [CrossRef] [PubMed]

2. Perkins, A.; Liu, G. Primary brain tumors in adults: Diagnosis and treatment. Am. Fam. Physician 2016, 93, 211-217.

3. Tai, Y.L.; Chen, K.C.; Hsieh, J.T.; Shen, T.L. Exosomes in cancer development and clinical applications. Cancer Sci. 2018, 109, 2364-2374. [CrossRef] [PubMed]

4. Zhang, Y.; Liu, Y.; Liu, H.; Tang, W.H. Exosomes: Biogenesis, biologic function and clinical potential. Cell Biosci. 2019, 9, 19. [CrossRef] [PubMed]

5. Zhang, L.; Yu, D. Exosomes in cancer development, metastasis, and immunity. Biochim. Biophys. Acta Rev. Cancer 2019, 1871, 455-468. [CrossRef] [PubMed]

6. Caruso Bavisotto, C.; Marino Gammazza, A.; Rappa, F.; Fucarino, A.; Pitruzzella, A.; David, S.; Campanella, C. Exosomes: Can doctors still ignore their existence? Euromediterranean Biomed. J. 2013, 8, 136-139.

7. Caruso Bavisotto, C.; Cappello, F.; Macario, A.J.L.; Conway de Macario, E.; Logozzi, M.; Fais, S.; Campanella, C. Exosomal HSP60: A potentially useful biomarker for diagnosis, assessing prognosis, and monitoring response to treatment. Expert Rev. Mol. Diagn. 2017, 17, 815-822. [CrossRef]

8. Campanella, C.; Rappa, F.; Sciumè, C.; Marino Gammazza, A.; Barone, R.; Bucchieri, F.; David, S.; Curcurù, G.; Caruso Bavisotto, C.; Pitruzzella, A.; et al. Heat shock protein 60 levels in tissue and circulating exosomes in human large bowel cancer before and after ablative surgery. Cancer 2015, 121, 3230-3239. [CrossRef]

9. Caruso Bavisotto, C.; Cipolla, C.; Graceffa, G.; Barone, R.; Bucchieri, F.; Bulone, D.; Cabibi, D.; Campanella, C.; Marino Gammazza, A.; Pitruzzella, A.; et al. Immunomorphological pattern of molecular chaperones in normal and pathological thyroid tissues and circulating exosomes: Potential use in clinics. Int. J. Mol. Sci. 2019, 20, 4496. [CrossRef]

10. Peng, Y.; Croce, C.M. The role of microRNAs in human cancer. Signal Transduct. Target. Ther. 2016, 1, 15004. [CrossRef]

11. Takahashi, R.U.; Prieto-Vila, M.; Hironaka, A.; Ochiya, T. The role of extracellular vesicle microRNAs in cancer biology. Clin. Chem. Lab. Med. 2017, 55, 648-656. [CrossRef] [PubMed] 
12. Lang, B.J.; Guerrero-Giménez, M.E.; Prince, T.L.; Ackerman, A.; Bonorino, C.; Calderwood, S.K. Heat shock proteins are essential components in transformation and tumor progression: Cancer cell intrinsic pathways and beyond. Int. J. Mol. Sci. 2019, 20, 4507. [CrossRef] [PubMed]

13. Graziano, F.; Caruso Bavisotto, C.; Marino Gammazza, A.; Rappa, F.; Conway de Macario, E.; Macario, A.J.L.; Cappello, F.; Campanella, C.; Maugeri, R.; Iacopino, D.G. Chaperonology: The third eye on brain gliomas. Brain Sci. 2018, 8, 110. [CrossRef] [PubMed]

14. Caruso Bavisotto, C.; Graziano, F.; Rappa, F.; Marino Gammazza, A.; Logozzi, M.; Fais, S.; Maugeri, R.; Bucchieri, F.; Conway de Macario, E.; Macario, A.J.L.; et al. Exosomal chaperones and miRNAs in gliomagenesis: State-of-art and theranostics perspectives. Int. J. Mol. Sci. 2018, 19, 2626. [CrossRef]

15. Marino Gammazza, A.; Caruso Bavisotto, C.; Barone, R.; Conway de Macario, E.; Macario, A.J.L. Alzheimer's disease and molecular chaperones: Current knowledge and the future of chaperonotherapy. Curr. Pharm. Des. 2016, 22, 4040-4049. [CrossRef]

16. Abels, E.R.; Breakefield, X.O. Introduction to extracellular vesicles: Biogenesis, rna cargo selection, content, release, and uptake. Cell. Mol. Neurobiol. 2016, 36, 301-312. [CrossRef]

17. Urbanelli, L.; Magini, A.; Buratta, S.; Brozzi, A.; Sagini, K.; Polchi, A.; Tancini, B.; Emiliani, C. Signaling pathways in exosomes biogenesis, secretion and fate. Genes (Basel) 2013, 4, 152-170. [CrossRef]

18. Perut, F.; Roncuzzi, L.; Baldini, N. The emerging roles of extracellular vesicles in osteosarcoma. Front. Oncol. 2019, 9, 1342. [CrossRef]

19. Caruso Bavisotto, C.; Scalia, F.; Marino Gammazza, A.; Carlisi, D.; Bucchieri, F.; Conway de Macario, E.; Macario, A.J.L.; Cappello, F.; Campanella, C. Extracellular vesicle-mediated Cell ${ }^{-}$Cell communication in the nervous system: Focus on neurological diseases. Int. J. Mol. Sci. 2019, 20, 434. [CrossRef]

20. Cufaro, M.C.; Pieragostino, D.; Lanuti, P.; Rossi, C.; Cicalini, I.; Federici, L.; De Laurenzi, V.; Del Boccio, P. Extracellular vesicles and their potential use in monitoring cancer progression and therapy: The contribution of proteomics. J. Oncol. 2019, 2019, 1639854. [CrossRef]

21. Cappello, F.; Logozzi, M.; Campanella, C.; Caruso Bavisotto, C.; Marcilla, A.; Properzi, F.; Fais, S. Exosome levels in human body fluids: A tumor marker by themselves? Eur. J. Pharm. Sci. 2017, 96, 93-98. [CrossRef] [PubMed]

22. Logozzi, M.; Mizzoni, D.; Bocca, B.; Di Raimo, R.; Petrucci, F.; Caimi, S.; Alimonti, A.; Falchi, M.; Cappello, F.; Campanella, C.; et al. Human primary macrophages scavenge AuNPs and eliminate it through exosomes. A natural shuttling for nanomaterials. Eur. J. Pharm. Biopharm. 2019, 137, 23-36. [CrossRef] [PubMed]

23. Théry, C.; Witwer, K.W.; Aikawa, E.; Alcaraz, M.J.; Anderson, J.D.; Andriantsitohaina, R.; Antoniou, A.; Arab, T.; Archer, F.; Atkin-Smith, G.K.; et al. Minimal information for studies of extracellular vesicles 2018 (MISEV2018): A position statement of the International Society for Extracellular Vesicles and update of the MISEV2014 guidelines. J. Extracell. Vesicles 2018, 7, 1535750. [CrossRef] [PubMed]

24. Cocucci, E.; Racchetti, G.; Meldolesi, J. Shedding microvesicles: Artefacts no more. Trends Cell Biol. 2009, 19, 43-51. [CrossRef]

25. Kakarla, R.; Hur, J.; Kim, Y.J.; Kim, J.; Chwae, Y.J. Apoptotic cell-derived exosomes: Messages from dying cells. Exp. Mol. Med. 2020, 52, 1-6. [CrossRef]

26. Xu, L.; Wu, L.-F.; Deng, F.-Y. Exosome: An emerging source of biomarkers for human diseases. Curr. Mol. Med. 2019, 19, 387-394. [CrossRef]

27. Reiner, A.T.; Witwer, K.W.; Van Balkom, B.W.M.; De Beer, J.; Brodie, C.; Corteling, R.L.; Gabrielsson, S.; Gimona, M.; Ibrahim, A.G.; De Kleijn, D.; et al. Concise review: Developing best-practice models for the therapeutic use of extracellular vesicles. Stem Cells Transl. Med. 2017, 6, 1730-1739. [CrossRef]

28. Burgio, S.; Noori, L.; Marino Gammazza, A.; Campanella, C.; Logozzi, M.; Fais, S.; Bucchieri, F.; Cappello, F.; Caruso Bavisotto, C. Extracellular vesicles-based drug delivery systems: A new challenge and the exemplum of malignant pleural mesothelioma. Int. J. Mol. Sci. 2020, 21, 5432. [CrossRef]

29. Nawaz, M.; Malik, M.I.; Hameed, M.; Zhou, J. Research progress on the composition and function of parasite-derived exosomes. Acta Trop. 2019, 196, 30-36. [CrossRef]

30. Van Dommelen, S.M.; Vader, P.; Lakhal, S.; Kooijmans, S.A.A.; Van Solinge, W.W.; Wood, M.J.A.; Schiffelers, R.M. Microvesicles and exosomes: Opportunities for cell-derived membrane vesicles in drug delivery. J. Control. Release 2012, 161, 635-644. [CrossRef] 
31. Bhome, R.; Del Vecchio, F.; Lee, G.H.; Bullock, M.D.; Primrose, J.N.; Sayan, A.E.; Mirnezami, A.H. Exosomal microRNAs (exomiRs): Small molecules with a big role in cancer. Cancer Lett. 2018, 420, 228-235. [CrossRef] [PubMed]

32. Théry, C.; Zitvogel, L.; Amigorena, S. Exosomes: Composition, biogenesis and function. Nat. Rev. Immunol. 2002, 2, 569-579. [CrossRef]

33. Kleihues, P.; Burger, P.C.; Scheithauer, B.W. The new WHO classification of brain tumours. Brain Pathol. 1993, 3, 255-268. [CrossRef] [PubMed]

34. Biernat, W. World health organization classification of tumors, of the nervous system. Pol. J. Pathol. 2000, 51, 107-114. [PubMed]

35. Kleihues, P.; Louis, D.N.; Scheithauer, B.W.; Rorke, L.B.; Reifenberger, G.; Burger, P.C.; Cavenee, W.K. The WHO classification of tumors of the nervous system. J. Neuropathol. Exp. Neurol. 2002, 61, 215-225. [CrossRef]

36. Louis, D.N.; Ohgaki, H.; Wiestler, O.D.; Cavenee, W.K.; Burger, P.C.; Jouvet, A.; Scheithauer, B.W.; Kleihues, P. The 2007 WHO classification of tumours of the central nervous system. Acta Neuropathol. 2007, 114, 97-109. [CrossRef] [PubMed]

37. Louis, D.N.; Perry, A.; Reifenberger, G.; von Deimling, A.; Figarella-Branger, D.; Cavenee, W.K.; Ohgaki, H.; Wiestler, O.D.; Kleihues, P.; Ellison, D.W. The 2016 world health organization classification of tumors of the central nervous system: A summary. Acta Neuropathol. 2016, 131, 803-820. [CrossRef]

38. Posner, J.B.; Chernik, N.L. Intracranial metastases from systemic cancer. Adv. Neurol. 1978, 19, 579-592.

39. Lapointe, S.; Perry, A.; Butowski, N.A. Primary brain tumours in adults. Lancet 2018, 392, 432-446. [CrossRef]

40. Achrol, A.S.; Rennert, R.C.; Anders, C.; Soffietti, R.; Ahluwalia, M.S.; Nayak, L.; Peters, S.; Arvold, N.D.; Harsh, G.R.; Steeg, P.S.; et al. Brain metastases. Nat. Rev. Dis. Prim. 2019, 5, 5. [CrossRef]

41. Gaspar, L.E. Brain metastases in lung cancer. Expert Rev. Anticancer 2004, 4, 259-270. [CrossRef] [PubMed]

42. Gállego Pérez-Larraya, J.; Hildebrand, J. Brain metastases. In Handbook of Clinical Neurology; Elsevier: Amsterdam, The Netherlands, 2014; Volume 121, pp. 1143-1157.

43. Michl, M.; Thurmaier, J.; Schubert-Fritschle, G.; Wiedemann, M.; Laubender, R.P.; Nüssler, N.C.; Ruppert, R.; Kleeff, J.; Schepp, W.; Reuter, C.; et al. Brain metastasis in colorectal cancer patients: Survival and analysis of prognostic factors. Clin. Colorectal Cancer 2015, 14, 281-290. [CrossRef] [PubMed]

44. Witzel, I.; Oliveira-Ferrer, L.; Pantel, K.; Müller, V.; Wikman, H. Breast cancer brain metastases: Biology and new clinical perspectives. Breast Cancer Res. 2016, 18, 8. [CrossRef] [PubMed]

45. Hemminki, K.; Li, X. Familial risks in nervous system tumors. Cancer Epidemiol. Prev. Biomark. 2003, 12, 1137-1142.

46. Goh, S.; Butler, W.; Thiele, E.A. Subependymal giant cell tumors in tuberous sclerosis complex. Neurology 2004, 63, 1457-1461. [CrossRef]

47. Farrell, C.J.; Plotkin, S.R. Genetic causes of brain tumors: Neurofibromatosis, tuberous sclerosis, von hippellindau, and other syndromes. Neurol. Clin. 2007, 25, 925-946. [CrossRef]

48. Hottinger, A.F.; Khakoo, Y. Neuro-oncology of neurofibromatosis type 1. Curr. Treat. Options Neurol. 2009, 11, 306-314. [CrossRef]

49. Kijima, C.; Miyashita, T.; Suzuki, M.; Oka, H.; Fujii, K. Two cases of nevoid basal cell carcinoma syndrome associated with meningioma caused by a PTCH1 or SUFU germline mutation. Fam. Cancer 2012, 11, 565-570. [CrossRef]

50. Braganza, M.Z.; Kitahara, C.M.; Berrington De González, A.; Inskip, P.D.; Johnson, K.J.; Rajaraman, P. Ionizing radiation and the risk of brain and central nervous system tumors: A systematic review. Neuro Oncol. 2012, 14, 1316-1324. [CrossRef]

51. Smoll, N.R.; Brady, Z.; Scurrah, K.; Mathews, J.D. Exposure to ionizing radiation and brain cancer incidence: The life span study cohort. Cancer Epidemiol. 2016, 42, 60-65. [CrossRef]

52. Libermann, T.A.; Nusbaum, H.R.; Razon, N.; Kris, R.; Lax, I.; Soreq, H.; Whittle, N.; Waterfield, M.D.; Ullrich, A.; Schlessinger, J. Amplification, enhanced expression and possible rearrangement of EGF receptor gene in primary human brain tumours of glial origin. Nature 1985, 313, 144-147. [CrossRef] [PubMed]

53. Kamb, A.; Gruis, N.A.; Weaver-Feldhaus, J.; Liu, Q.; Harshman, K.; Tavtigian, S.V.; Stockert, E.; Day, R.S.; Johnson, B.E.; Skolnick, M.H. A cell cycle regulator potentially involved in genesis of many tumor types. Science 1994, 264, 436-440. [CrossRef] [PubMed] 
54. Ebert, C.; Von Haken, M.; Meyer-Puttlitz, B.; Wiestler, O.D.; Reifenberger, G.; Pietsch, T.; Von Deimling, A. Molecular genetic analysis of ependymal tumors: NF2 mutations and chromosome 22q loss occur preferentially in intramedullary spinal ependymomas. Am. J. Pathol. 1999, 155, 627-632. [CrossRef]

55. Wani, K.; Armstrong, T.S.; Vera-Bolanos, E.; Raghunathan, A.; Ellison, D.; Gilbertson, R.; Vaillant, B.; Goldman, S.; Packer, R.J.; Fouladi, M.; et al. A prognostic gene expression signature in infratentorial ependymoma. Acta Neuropathol. 2012, 123, 727-738. [CrossRef]

56. Gupta, K.; Salunke, P. Understanding Ependymoma oncogenesis: An Update on recent molecular advances and current perspectives. Mol. Neurobiol. 2017, 54, 15-21. [CrossRef]

57. Li, J.; Yen, C.; Liaw, D.; Podsypanina, K.; Bose, S.; Wang, S.I.; Puc, J.; Miliaresis, C.; Rodgers, L.; McCombie, R.; et al. PTEN, a putative protein tyrosine phosphatase gene mutated in human brain, breast, and prostate cancer. Science 1997, 275, 1943-1947. [CrossRef]

58. Nigro, J.M.; Baker, S.J.; Preisinger, A.C.; Jessup, J.M.; Hosteller, R.; Cleary, K.; Bigner, S.H.; Davidson, N.; Baylin, S.; Devilee, P.; et al. Mutations in the p53 gene occur in diverse human tumour types. Nature 1989, 342, 705-708. [CrossRef]

59. Wolter, M.; Reifenberger, J.; Blaschke, B.; Ichimura, K.; Schmidt, E.E.; Collins, V.P.; Reifenberger, G. Oligodendroglial tumors frequently demonstrate hypermethylation of the CDKN2A (MTS1, p16INK4a), p14ARF, and CDKN2B (MTS2, p15INK4b) tumor suppressor genes. J. Neuropathol. Exp. Neurol. 2001, 60, 1170-1180. [CrossRef]

60. Bortolotto, S.; Chiadò-Piat, L.; Cavalla, P.; Bosone, I.; Chiò, A.; Mauro, A.; Schiffer, D. CDKN2A/p16 inactivation in the prognosis of oligodendrogliomas. Int. J. Cancer 2000, 88, 554-557. [CrossRef]

61. Watanabe, T.; Nobusawa, S.; Kleihues, P.; Ohgaki, H. IDH1 mutations are early events in the development of astrocytomas and oligodendrogliomas. Am. J. Pathol. 2009, 174, 1149-1153. [CrossRef]

62. Costa, F.F.; Bischof, J.M.; Vanin, E.F.; Lulla, R.R.; Wang, M.; Sredni, S.T.; Rajaram, V.; de Fátima Bonaldo, M.; Wang, D.; Goldman, S.; et al. Identification of micrornas as potential prognostic markers in ependymoma. PloS ONE 2011, 6, e25114. [CrossRef] [PubMed]

63. Taylor, M.D.; Poppleton, H.; Fuller, C.; Su, X.; Liu, Y.; Jensen, P.; Magdaleno, S.; Dalton, J.; Calabrese, C.; Board, J.; et al. Radial glia cells are candidate stem cells of ependymoma. Cancer Cell 2005, 8, 323-335. [CrossRef]

64. Peyre, M.; Commo, F.; Dantas-Barbosa, C.; Andreiuolo, F.; Puget, S.; Lacroix, L.; Drusch, F.; Scott, V.; Varlet, P.; Mauguen, A.; et al. Portrait of ependymoma recurrence in children: Biomarkers of tumor progression identified by dual- color microarray-based gene expression analysis. PloS ONE 2010, 5, e12932. [CrossRef] [PubMed]

65. Hartmann, C.; Sieberns, J.; Gehlhaar, C.; Simon, M.; Paulus, W.; von Deimling, A. NF2 mutations in secretory and other rare variants of meningiomas. Brain Pathol. 2006, 16, 15-19. [CrossRef] [PubMed]

66. Gutmann, D.H.; Donahoe, J.; Perry, A.; Lemke, N.; Gorse, K.; Kittiniyom, K.; Rempel, S.A.; Gutierrez, J.A.; Newsham, I.F. Loss of DAL-1, a protein 4.1-related tumor suppressor, is an important early event in the pathogenesis of meningiomas. Hum. Mol. Genet. 2000, 9, 1495-1500. [CrossRef]

67. Peters, N.; Wellenreuther, R.; Rollbrocker, B.; Hayashi, Y.; Meyer-Puttlitz, B.; Duerr, E.M.; Lenartz, D.; Marsh, D.J.; Schramm, J.; Wiestler, O.D.; et al. Analysis of the PTEN gene in human meningiomas. Neuropathol. Appl. Neurobiol. 1998, 24, 3-8. [CrossRef] [PubMed]

68. Carvalho, L.H.; Smirnov, I.; Baia, G.S.; Modrusan, Z.; Smith, J.S.; Jun, P.; Costello, J.F.; McDermott, M.W.; VandenBerg, S.R.; Lal, A. Molecular signatures define two main classes of meningiomas. Mol. Cancer 2007, 6, 64. [CrossRef]

69. Arnli, M.B.; Backer-Grøndahl, T.; Ytterhus, B.; Granli, U.S.; Lydersen, S.; Gulati, S.; Torp, S.H. Expression and clinical value of EGFR in human meningiomas. PeerJ 2017, 2017, e3140. [CrossRef]

70. Pfaff, E.; Remke, M.; Sturm, D.; Benner, A.; Witt, H.; Milde, T.; Von Bueren, A.O.; Wittmann, A.; Schöttler, A.; Jorch, N.; et al. TP53 mutation is frequently associated with CTNNB1 mutation or MYCN amplification and is compatible with long-term survival in medulloblastoma. J. Clin. Oncol. 2010, 28, 5188-5196. [CrossRef]

71. Hernan, R.; Fasheh, R.; Calabrese, C.; Frank, A.J.; Maclean, K.H.; Allard, D.; Barraclough, R.; Gilbertson, R.J. ERBB2 up-regulates S100A4 and several other prometastatic genes in medulloblastoma. Cancer Res. 2003, 63, 140-148. [PubMed] 
72. Grotzer, M.A.; Janss, A.J.; Phillips, P.C.; Trojanowski, J.Q. Neurotrophin receptor TrkC predicts good clinical outcome in medulloblastoma and other primitive neuroectodermal brain tumors. Klin. Padiatr. 2000, 212, 196-199. [CrossRef] [PubMed]

73. Eberhart, C.G.; Kratz, J.; Wang, Y.; Summers, K.; Stearns, D.; Cohen, K.; Dang, C.V.; Burger, P.C. Histopathological and molecular prognostic markers in medulloblastoma: C-myc, N-myc, TrkC, and Anaplasia. J. Neuropathol. Exp. Neurol. 2004, 63, 441-449. [CrossRef] [PubMed]

74. Raffel, C.; Jenkins, R.B.; Frederick, L.; Hebrink, D.; Alderete, B.; Fults, D.W.; David James, C. Sporadic medulloblastomas contain PTCH mutations. Cancer Res. 1997, 57, 842-845. [PubMed]

75. Eberhart, C.G.; Tihan, T.; Burger, P.C. Nuclear localization and mutation of $\beta$-catenin in medulloblastomas. J. Neuropathol. Exp. Neurol. 2000, 59, 333-337. [CrossRef] [PubMed]

76. Northcott, P.A.; Buchhalter, I.; Morrissy, A.S.; Hovestadt, V.; Weischenfeldt, J.; Ehrenberger, T.; Gröbner, S.; Segura-Wang, M.; Zichner, T.; Rudneva, V.A.; et al. The whole-genome landscape of medulloblastoma subtypes. Nature 2017, 547, 311-317. [CrossRef]

77. Northcott, P.A.; Shih, D.J.H.; Peacock, J.; Garzia, L.; Sorana Morrissy, A.; Zichner, T.; Stútz, A.M.; Korshunov, A.; Reimand, J.; Schumacher, S.E.; et al. Subgroup-specific structural variation across 1,000 medulloblastoma genomes. Nature 2012, 487, 49-56. [CrossRef] [PubMed]

78. Tantravedi, S.; Vesuna, F.; Winnard, P.T.; Martin, A.; Lim, M.; Eberhart, C.G.; Berlinicke, C.; Raabe, E.; van Diest, P.J.; Raman, V. Targeting DDX3 in medulloblastoma using the small molecule inhibitor RK-33. Transl. Oncol. 2019, 12, 96-105. [CrossRef]

79. Sanai, N.; Polley, M.Y.; Berger, M.S. Insular glioma resection: Assessment of patient morbidity, survival, and tumor progression-Clinical article. J. Neurosurg. 2010, 112, 1-9. [CrossRef]

80. Ius, T.; Isola, M.; Budai, R.; Pauletto, G.; Tomasino, B.; Fadiga, L.; Skrap, M. Low-grade glioma surgery in eloquent areas: Volumetric analysis of extent of resection and its impact on overall survival. A singleinstitution experience in 190 patients-Clinical article. J. Neurosurg. 2012, 117, 1039-1052. [CrossRef]

81. Mansoori, B.; Mohammadi, A.; Davudian, S.; Shirjang, S.; Baradaran, B. The different mechanisms of cancer drug resistance: A brief review. Adv. Pharm. Bull. 2017, 7, 339-348. [CrossRef]

82. Ostrom, Q.T.; Cioffi, G.; Gittleman, H.; Patil, N.; Waite, K.; Kruchko, C.; Barnholtz-Sloan, J.S. CBTRUS statistical report: Primary brain and other central nervous system tumors diagnosed in the United States in 2012-2016. Neuro Oncol. 2019, 21, V1-V100. [CrossRef] [PubMed]

83. Patel, A.P.; Fisher, J.L.; Nichols, E.; Abd-Allah, F.; Abdela, J.; Abdelalim, A.; Abraha, H.N.; Agius, D.; Alahdab, F.; Alam, T.; et al. Global, regional, and national burden of brain and other CNS cancer, 1990-2016: A systematic analysis for the Global Burden of Disease Study 2016. Lancet Neurol. 2019, 18, 376-393. [CrossRef]

84. Osei, E.; Walters, P.; Masella, O.; Tennant, Q.; Fishwick, A.; Dadzie, E.; Bhangu, A.; Darko, J. A review of predictive, prognostic and diagnostic biomarkers for brain tumours: Towards personalised and targeted cancer therapy. J. Radiother. Pract. 2019, 1-16. [CrossRef]

85. Bartel, D.P. MicroRNAs: Genomics, biogenesis, mechanism, and function. Cell 2004, 116, 281-297. [CrossRef]

86. Lee, Y.; Jeon, K.; Lee, J.T.; Kim, S.; Kim, V.N. MicroRNA maturation: Stepwise processing and subcellular localization. EMBO J. 2002, 21, 4663-4670. [CrossRef] [PubMed]

87. Lee, Y.; Kim, M.; Han, J.; Yeom, K.H.; Lee, S.; Baek, S.H.; Kim, V.N. MicroRNA genes are transcribed by RNA polymerase II. EMBO J. 2004, 23, 4051-4060. [CrossRef]

88. Lee, Y.; Ahn, C.; Han, J.; Choi, H.; Kim, J.; Yim, J.; Lee, J.; Provost, P.; Rådmark, O.; Kim, S.; et al. The nuclear RNase III Drosha initiates microRNA processing. Nature 2003, 425, 415-419. [CrossRef]

89. Han, J.; Lee, Y.; Yeom, K.H.; Kim, Y.K.; Jin, H.; Kim, V.N. The Drosha-DGCR8 complex in primary microRNA processing. Genes Dev. 2004, 18, 3016-3027. [CrossRef]

90. Cai, X.; Hagedorn, C.H.; Cullen, B.R. Human microRNAs are processed from capped, polyadenylated transcripts that can also function as mRNAs. RNA 2004, 10, 1957-1966. [CrossRef]

91. Morlando, M.; Ballarino, M.; Gromak, N.; Pagano, F.; Bozzoni, I.; Proudfoot, N.J. Primary microRNA transcripts are processed co-transcriptionally. Nat. Struct. Mol. Biol. 2008, 15, 902-909. [CrossRef]

92. Denli, A.M.; Tops, B.B.J.; Plasterk, R.H.A.; Ketting, R.F.; Hannon, G.J. Processing of primary microRNAs by the Microprocessor complex. Nature 2004, 432, 231-235. [CrossRef] [PubMed]

93. Bohnsack, M.T.; Czaplinski, K.; Görlich, D. Exportin 5 is a RanGTP-dependent dsRNA-binding protein that mediates nuclear export of pre-miRNAs. RNA 2004, 10, 185-191. [CrossRef] [PubMed] 
94. Bernstein, E.; Caudy, A.A.; Hammond, S.M.; Hannon, G.J. Role for a bidentate ribonuclease in the initiation step of RNA interference. Nature 2001, 409, 363-366. [CrossRef]

95. Hutvágner, G.; McLachlan, J.; Pasquinelli, A.E.; Bálint, É.; Tuschl, T.; Zamore, P.D. A cellular function for the RNA-interference enzyme dicer in the maturation of the let-7 small temporal RNA. Science 2001, 293, 834-838. [CrossRef] [PubMed]

96. Ketting, R.F.; Fischer, S.E.J.; Bernstein, E.; Sijen, T.; Hannon, G.J.; Plasterk, R.H.A. Dicer functions in RNA interference and in synthesis of small RNA involved in developmental timing in C. elegans. Genes Dev. 2001, 15, 2654-2659. [CrossRef]

97. Park, J.E.; Heo, I.; Tian, Y.; Simanshu, D.K.; Chang, H.; Jee, D.; Patel, D.J.; Kim, V.N. Dicer recognizes the $5^{\prime}$ end of RNA for efficient and accurate processing. Nature 2011, 475, 201-205. [CrossRef]

98. Olsen, P.H.; Ambros, V. The lin-4 regulatory RNA controls developmental timing in Caenorhabditis elegans by blocking LIN-14 protein synthesis after the initiation of translation. Dev. Biol. 1999, 216, 671-680. [CrossRef]

99. Liu, J.; Carmell, M.A.; Rivas, F.V.; Marsden, C.G.; Thomson, J.M.; Song, J.J.; Hammond, S.M.; Joshua-Tor, L.; Hannon, G.J. Argonaute2 is the catalytic engine of mammalian RNAi. Science 2004, 305, 1437-1441. [CrossRef]

100. Gregory, R.I.; Chendrimada, T.P.; Cooch, N.; Shiekhattar, R. Human RISC couples microRNA biogenesis and posttranscriptional gene silencing. Cell 2005, 123, 631-640. [CrossRef]

101. Lytle, J.R.; Yario, T.A.; Steitz, J.A. Target mRNAs are repressed as efficiently by microRNA-binding sites in the 5' UTR as in the 3' UTR. Proc. Natl. Acad. Sci. USA 2007, 104, 9667-9672. [CrossRef]

102. Guo, H.; Ingolia, N.T.; Weissman, J.S.; Bartel, D.P. Mammalian microRNAs predominantly act to decrease target mRNA levels. Nature 2010, 466, 835-840. [CrossRef] [PubMed]

103. Meister, G.; Landthaler, M.; Patkaniowska, A.; Dorsett, Y.; Teng, G.; Tuschl, T. Human Argonaute2 mediates RNA cleavage targeted by miRNAs and siRNAs. Mol. Cell 2004, 15, 185-197. [CrossRef] [PubMed]

104. Seggerson, K.; Tang, L.; Moss, E.G. Two genetic circuits repress the Caenorhabditis elegans heterochronic gene lin-28 after translation initiation. Dev. Biol. 2002, 243, 215-225. [CrossRef] [PubMed]

105. miRbase. Available online: http://www.mirbase.org/help/nomenclature.shtml (accessed on 23 September 2020).

106. Lee, R.C.; Feinbaum, R.L.; Ambros, V. The C. elegans heterochronic gene lin-4 encodes small RNAs with antisense complementarity to lin-14. Cell 1993, 75, 843-854. [CrossRef]

107. Wightman, B.; Ha, I.; Ruvkun, G. Posttranscriptional regulation of the heterochronic gene lin-14 by lin-4 mediates temporal pattern formation in C. elegans. Cell 1993, 75, 855-862. [CrossRef]

108. Grad, Y.; Aach, J.; Hayes, G.D.; Reinhart, B.J.; Church, G.M.; Ruvkun, G.; Kim, J. Computational and experimental identification of C. elegans microRNAs. Mol. Cell 2003, 11, 1253-1263. [CrossRef]

109. Griffiths-Jones, S. The microRNA registry. Nucleic Acids Res. 2004, 32, D109-D111. [CrossRef]

110. Huang, T.H.; Fan, B.; Rothschild, M.F.; Hu, Z.L.; Li, K.; Zhao, S.H. MiRFinder: An improved approach and software implementation for genome-wide fast microRNA precursor scans. BMC Bioinform. 2007, 8, 341. [CrossRef]

111. Friedländer, M.R.; Chen, W.; Adamidi, C.; Maaskola, J.; Einspanier, R.; Knespel, S.; Rajewsky, N. Discovering microRNAs from deep sequencing data using miRDeep. Nat. Biotechnol. 2008, 26, 407-415. [CrossRef]

112. Lewis, B.P.; Shih, I.H.; Jones-Rhoades, M.W.; Bartel, D.P.; Burge, C.B. Prediction of mammalian microRNA targets. Cell 2003, 115, 787-798. [CrossRef]

113. Sethupathy, P.; Megraw, M.; Hatzigeorgiou, A.G. A guide through present computational approaches for the identification of mammalian microRNA targets. Nat. Methods 2006, 3, 881-886. [CrossRef] [PubMed]

114. Ritchie, W. MicroRNA target prediction. In Methods in Molecular Biology; Humana Press Inc.: Totowa, NJ, USA, 2017; Volume 1513, pp. 193-200.

115. Alles, J.; Fehlmann, T.; Fischer, U.; Backes, C.; Galata, V.; Minet, M.; Hart, M.; Abu-Halima, M.; Grässer, F.A.; Lenhof, H.P.; et al. An estimate of the total number of true human miRNAs. Nucleic Acids Res. 2019, 47, 3353-3364. [CrossRef] [PubMed]

116. Friedländer, M.R.; Lizano, E.; Houben, A.J.S.; Bezdan, D.; Báñez-Coronel, M.; Kudla, G.; Mateu-Huertas, E.; Kagerbauer, B.; González, J.; Chen, K.C.; et al. Evidence for the biogenesis of more than 1000 novel human microRNAs. Genome Biol. 2014, 15, R57. [CrossRef] [PubMed]

117. Lewis, B.P.; Burge, C.B.; Bartel, D.P. Conserved seed pairing, often flanked by adenosines, indicates that thousands of human genes are microRNA targets. Cell 2005, 120, 15-20. [CrossRef] [PubMed] 
118. Chen, J.F.; Mandel, E.M.; Thomson, J.M.; Wu, Q.; Callis, T.E.; Hammond, S.M.; Conlon, F.L.; Wang, D.Z. The role of microRNA-1 and microRNA-133 in skeletal muscle proliferation and differentiation. Nat. Genet. 2006, 38, 228-233. [CrossRef] [PubMed]

119. Sugatani, T.; Hruska, K.A. Impaired micro-RNA pathways diminish osteoclast differentiation and function. J. Biol. Chem. 2009, 284, 4667-4678. [CrossRef]

120. Shi, Y.; Jin, Y.X. MicroRNA in cell differentiation and development. Sci. China Ser. C Life Sci. 2009, 52, $205-211$. [CrossRef]

121. Tzur, G.; Israel, A.; Levy, A.; Benjamin, H.; Meiri, E.; Shufaro, Y.; Meir, K.; Khvalevsky, E.; Spector, Y.; Rojansky, N.; et al. Comprehensive gene and microRNA expression profiling reveals a role for microRNAs in human liver development. PloS ONE 2009, 4, e7511. [CrossRef]

122. Calin, G.A.; Dumitru, C.D.; Shimizu, M.; Bichi, R.; Zupo, S.; Noch, E.; Aldler, H.; Rattan, S.; Keating, M.; Rai, K.; et al. Frequent deletions and down-regulation of micro- RNA genes miR15 and miR16 at 13q14 in chronic lymphocytic leukemia. Proc. Natl. Acad. Sci. USA 2002, 99, 15524-15529. [CrossRef]

123. Zhang, B.; Pan, X.; Cobb, G.P.; Anderson, T.A. MicroRNAs as oncogenes and tumor suppressors. Dev. Biol. 2007, 302, 1-12. [CrossRef]

124. Svoronos, A.A.; Engelman, D.M.; Slack, F.J. OncomiR or tumor suppressor? The duplicity of MicroRNAs in cancer. Cancer Res. 2016, 76, 3666-3670. [CrossRef] [PubMed]

125. Hayashita, Y.; Osada, H.; Tatematsu, Y.; Yamada, H.; Yanagisawa, K.; Tomida, S.; Yatabe, Y.; Kawahara, K.; Sekido, Y.; Takahashi, T. A polycistronic MicroRNA cluster, miR-17-92, is overexpressed in human lung cancers and enhances cell proliferation. Cancer Res. 2005, 65, 9628-9632. [CrossRef] [PubMed]

126. Chang, T.C.; Yu, D.; Lee, Y.S.; Wentzel, E.A.; Arking, D.E.; West, K.M.; Dang, C.V.; Thomas-Tikhonenko, A.; Mendell, J.T. Widespread microRNA repression by Myc contributes to tumorigenesis. Nat. Genet. 2008, 40, 43-50. [CrossRef]

127. Wong, Q.W.L.; Lung, R.W.M.; Law, P.T.Y.; Lai, P.B.S.; Chan, K.Y.Y.; To, K.F.; Wong, N. MicroRNA-223 is commonly repressed in hepatocellular carcinoma and potentiates expression of stathmin1. Gastroenterology 2008, 135, 257-269. [CrossRef] [PubMed]

128. Lehmann, U.; Hasemeier, B.; Christgen, M.; Müller, M.; Römermann, D.; Länger, F.; Kreipe, H. Epigenetic inactivation of microRNA gene hsa-mir-9-1 in human breast cancer. J. Pathol. 2008, 214, 17-24. [CrossRef] [PubMed]

129. Saito, Y.; Liang, G.; Egger, G.; Friedman, J.M.; Chuang, J.C.; Coetzee, G.A.; Jones, P.A. Specific activation of microRNA-127 with downregulation of the proto-oncogene BCL6 by chromatin-modifying drugs in human cancer cells. Cancer Cell 2006, 9, 435-443. [CrossRef] [PubMed]

130. Walz, A.L.; Ooms, A.; Gadd, S.; Gerhard, D.S.; Smith, M.A.; Guidry Auvil, J.M.; Meerzaman, D.; Chen, Q.-R.; Hsu, C.H.; Yan, C.; et al. Recurrent DGCR8, DROSHA, and SIX homeodomain mutations in favorable histology Wilms tumors. Cancer Cell 2015, 27, 286-297. [CrossRef] [PubMed]

131. Iliou, M.S.; Da Silva-Diz, V.; Carmona, F.J.; Ramalho-Carvalho, J.; Heyn, H.; Villanueva, A.; Muñoz, P.; Esteller, M. Impaired DICER1 function promotes stemness and metastasis in colon cancer. Oncogene 2014, 33, 4003-4015. [CrossRef]

132. Ciafrè, S.A.; Galardi, S.; Mangiola, A.; Ferracin, M.; Liu, C.G.; Sabatino, G.; Negrini, M.; Maira, G.; Croce, C.M.; Farace, M.G. Extensive modulation of a set of microRNAs in primary glioblastoma. Biochem. Biophys. Res. Commun. 2005, 334, 1351-1358. [CrossRef]

133. Shi, L.; Cheng, Z.; Zhang, J.; Li, R.; Zhao, P.; Fu, Z.; You, Y. Hsa-mir-181a and hsa-mir-181b function as tumor suppressors in human glioma cells. Brain Res. 2008, 1236, 185-193. [CrossRef]

134. Li, W.B.; Ma, M.W.; Dong, L.J.; Wang, F.; Chen, L.X.; Li, X.R. MicroRNA-34a targets notch1 and inhibits cell proliferation in glioblastoma multiforme. Cancer Biol. 2011, 12, 477-483. [CrossRef] [PubMed]

135. Liu, F.; Xiong, Y.; Zhao, Y.; Tao, L.; Zhang, Z.; Zhang, H.; Liu, Y.; Feng, G.; Li, B.; He, L.; et al. Identification of aberrant microRNA expression pattern in pediatric gliomas by microarray. Diagn. Pathol. 2013, 8, 158. [CrossRef] [PubMed]

136. Zhu, X.P.; Mou, K.J.; Xu, Q.F.; Tang, J.H.; Huang, G.H.; Xu, J.P.; Li, G.H.; Ai, S.J.; Hugnot, J.P.; Zhou, Z.; et al. Microarray analysis of the aberrant microRNA expression pattern in gliomas of different grades. Oncol. Rep. 2015, 34, 318-324. [CrossRef] [PubMed]

137. Sun, J.; Shi, H.; Lai, N.; Liao, K.; Zhang, S.; Lu, X. Overexpression of microRNA-155 predicts poor prognosis in glioma patients. Med. Oncol. 2014, 31, 911. [CrossRef] [PubMed] 
138. Liu, Q.; Zou, R.; Zhou, R.; Gong, C.; Wang, Z.; Cai, T.; Tan, C.; Fang, J. MiR-155 regulates glioma cells invasion and chemosensitivity by p38 isforms in vitro. J. Cell. Biochem. 2015, 116, 1213-1221. [CrossRef]

139. Wu, W.; Yu, T.; Wu, Y.; Tian, W.; Zhang, J.; Wang, Y. The miR155HG/miR-185/ANXA2 loop contributes to glioblastoma growth and progression. J. Exp. Clin. Cancer Res. 2019, 38, 133. [CrossRef]

140. Chen, G.; Chen, Z.; Zhao, H. MicroRNA-155-3p promotes glioma progression and temozolomide resistance by targeting Six1. J. Cell. Mol. Med. 2020, 24, 5363-5374. [CrossRef]

141. Zhang, C.; Zhang, J.; Hao, J.; Shi, Z.; Wang, Y.; Han, L.; Yu, S.; You, Y.; Jiang, T.; Wang, J.; et al. High level of miR-221/222 confers increased cell invasion and poor prognosis in glioma. J. Transl. Med. 2012, 10, 119. [CrossRef]

142. Zhang, R.; Pang, B.; Xin, T.; Guo, H.; Xing, Y.; Xu, S.; Feng, B.; Liu, B.; Pang, Q. Plasma miR-221/222 Family as novel descriptive and prognostic biomarkers for glioma. Mol. Neurobiol. 2016, 53, 1452-1460. [CrossRef]

143. Zhang, J.; Han, L.; Ge, Y.; Zhou, X.; Zhang, A.; Zhang, C.; Zhong, Y.; You, Y.; Pu, P.; Kang, C. MiR-221/222 promote malignant progression of glioma through activation of the Akt pathway. Int. J. Oncol. 2010, 36, 913-920.

144. Zhang, C.; Kang, C.; You, Y.; Pu, P.; Yang, W.; Zhao, P.; Wang, G.; Wang, A.; Jia, Z.; Han, L.; et al. Co-suppression of miR-221/222 cluster suppresses human glioma cell growth by targeting p27kip1 in vitro and in vivo. Int. J. Oncol. 2009, 34, 1653-1660. [PubMed]

145. Chen, L.; Zhang, J.; Han, L.; Zhang, A.; Zhang, C.; Zheng, Y.; Jiang, T.; Pu, P.; Jiang, C.; Kang, C. Downregulation of miR-221/222 sensitizes glioma cells to temozolomide by regulating apoptosis independently of p53 status. Oncol. Rep. 2012, 27, 854-860. [PubMed]

146. Tang, H.; Liu, Q.; Liu, X.; Ye, F.; Xie, X.; Xie, X.; Wu, M. Plasma miR-185 as a predictive biomarker for prognosis of malignant glioma. J. Cancer Res. 2015, 11, 630-634.

147. Yue, X.; Lan, F.; Hu, M.; Pan, Q.; Wang, Q.; Wang, J. Downregulation of serum microRNA-205 as a potential diagnostic and prognostic biomarker for human glioma. J. Neurosurg. 2016, 124, 122-128. [CrossRef]

148. Yue, X.; Wang, P.; Xu, J.; Zhu, Y.; Sun, G.; Pang, Q.; Tao, R. MicroRNA-205 functions as a tumor suppressor in human glioblastoma cells by targeting VEGF-A. Oncol. Rep. 2012, 27, 1200-1206. [CrossRef]

149. Tang, H.; Wang, Z.; Liu, X.; Liu, Q.; Xu, G.; Li, G.; Wu, M. LRRC4 inhibits glioma cell growth and invasion through a miR-185- dependent pathway. Curr. Cancer Drug Targets 2012, 12, 1032-1042. [CrossRef]

150. Batash, R.; Asna, N.; Schaffer, P.; Francis, N.; Schaffer, M. Glioblastoma multiforme, diagnosis and treatment; Recent literature review. Curr. Med. Chem. 2017, 24, 3002-3009. [CrossRef]

151. Chen, J.; Yang, L.; Wang, X. Reduced circulating microRNA-203 predicts poor prognosis for glioblastoma. Cancer Biomark. 2017, 20, 521-526. [CrossRef]

152. Liao, H.; Bai, Y.; Qiu, S.; Zheng, L.; Huang, L.; Liu, T.; Wang, X.; Liu, Y.; Xu, N.; Yan, X.; et al. MiR-203 downregulation is responsible for chemoresistance in human glioblastoma by promoting epithelialmesenchymal transition via SNAI2. Oncotarget 2015, 6, 8914-8928. [CrossRef]

153. Jia, J.; Wang, J.; Yin, M.; Liu, Y. MicroRNA-605 directly targets sox 9 to alleviate the aggressive phenotypes of glioblastoma multiforme cell lines by deactivating the PI3K/Akt pathway. Onco Targets Ther. 2019, 12, 5437-5448. [CrossRef]

154. Saydam, O.; Shen, Y.; Würdinger, T.; Senol, O.; Boke, E.; James, M.F.; Tannous, B.A.; Stemmer-Rachamimov, A.O.; Yi, M.; Stephens, R.M.; et al. Downregulated microRNA-200a in meningiomas promotes tumor growth by reducing E-cadherin and activating the Wnt/ $\beta$-catenin signaling pathway. Mol. Cell. Biol. 2009, 29, 5923-5940. [CrossRef] [PubMed]

155. Senol, O.; Schaaij-Visser, T.B.M.; Erkan, E.P.; Dorfer, C.; Lewandrowski, G.; Pham, T.V.; Piersma, S.R.; Peerdeman, S.M.; Ströbel, T.; Tannous, B.; et al. MiR-200a-mediated suppression of non-muscle heavy chain $\mathrm{IIb}$ inhibits meningioma cell migration and tumor growth in vivo. Oncogene 2014, 34, 1790-1798. [CrossRef] [PubMed]

156. Kliese, N.; Gobrecht, P.; Pachow, D.; Andrae, N.; Wilisch-Neumann, A.; Kirches, E.; Riek-Burchardt, M.; Angenstein, F.; Reifenberger, G.; Riemenschneider, M.; et al. MiRNA-145 is downregulated in atypical and anaplastic meningiomas and negatively regulates motility and proliferation of meningioma cells. Oncogene 2013, 32, 4712-4720. [CrossRef]

157. Shi, L.; Jiang, D.; Sun, G.; Wan, Y.; Zhang, S.; Zeng, Y.; Pan, T.; Wang, Z. MiR-335 promotes cell proliferation by directly targeting Rb1 in meningiomas. J. Neurooncol. 2012, 110, 155-162. [CrossRef] [PubMed] 
158. Shu, M.; Zheng, X.; Wu, S.; Lu, H.; Leng, T.; Zhu, W.; Zhou, Y.; Ou, Y.; Lin, X.; Lin, Y.; et al. Targeting oncogenic miR-335 inhibits growth and invasion of malignant astrocytoma cells. Mol. Cancer 2011, 10, 59. [CrossRef]

159. Wang, M.; Deng, X.; Ying, Q.; Jin, T.; Li, M.; Liang, C. MicroRNA-224 targets ERG2 and contributes to malignant progressions of meningioma. Biochem. Biophys. Res. Commun. 2015, 460, 354-361. [CrossRef]

160. Zhi, F.; Shao, N.; Li, B.; Xue, L.; Deng, D.; Xu, Y.; Lan, Q.; Peng, Y.; Yang, Y. A serum 6-miRNA panel as a novel non-invasive biomarker for meningioma. Sci. Rep. 2016, 6, 32067. [CrossRef]

161. Slavik, H.; Balik, V.; Vrbkova, J.; Rehulkova, A.; Vaverka, M.; Hrabalek, L.; Ehrmann, J.; Vidlarova, M.; Gurska, S.; Hajduch, M.; et al. Identification of meningioma patients at high risk of tumor recurrence using microRNA profiling. Neurosurgery 2020,3, nyaa009. [CrossRef]

162. Xiao, F.; Lv, S.; Zong, Z.; Wu, L.; Tang, X.; Kuang, W.; Zhang, P.; Li, X.; Fu, J.; Xiao, M.; et al. Cerebrospinal fluid biomarkers for brain tumor detection: Clinical roles and current progress. Am. J. Transl. Res. 2020, 12, 1379-1396.

163. Drusco, A.; Bottoni, A.; Lagana', A.; Acunzo, M.; Fassan, M.; Cascione, L.; Antenucci, A.; Kumchala, P.; Vicentini, C.; Gardiman, M.P.; et al. A differentially expressed set of microRNAs in cerebro-spinal fluid (CSF) can diagnose CNS malignancies. Oncotarget 2015, 6, 20829-20839. [CrossRef]

164. Petrescu, G.E.D.; Sabo, A.A.; Torsin, L.I.; Calin, G.A.; Dragomir, M.P. MicroRNA based theranostics for brain cancer: Basic principles. J. Exp. Clin. Cancer Res. 2019, 38, 231. [CrossRef] [PubMed]

165. Baraniskin, A.; Kuhnhenn, J.; Schlegel, U.; Maghnouj, A.; Zöllner, H.; Schmiegel, W.; Hahn, S.; Schroers, R. Identification of microRNAs in the cerebrospinal fluid as biomarker for the diagnosis of glioma. Neuro Oncol. 2012, 14, 29-33. [CrossRef] [PubMed]

166. Kopkova, A.; Sana, J.; Machackova, T.; Vecera, M.; Radova, L.; Trachtova, K.; Vybihal, V.; Smrcka, M.; Kazda, T.; Slaby, O.; et al. Cerebrospinal fluid microRNA signatures as diagnostic biomarkers in brain tumors. Cancers 2019, 11, 1546. [CrossRef]

167. Teplyuk, N.M.; Mollenhauer, B.; Gabriely, G.; Giese, A.; Kim, E.; Smolsky, M.; Kim, R.Y.; Saria, M.G.; Pastorino, S.; Kesari, S.; et al. MicroRNAs in cerebrospinal fluid identify glioblastoma and metastatic brain cancers and reflect disease activity. Neuro Oncol. 2012, 14, 689-700. [CrossRef] [PubMed]

168. van der Vos, K.E.; Abels, E.R.; Zhang, X.; Lai, C.; Carrizosa, E.; Oakley, D.; Prabhakar, S.; Mardini, O.; Crommentuijn, M.H.W.; Skog, J.; et al. Directly visualized glioblastoma-derived extracellular vesicles transfer RNA to microglia/macrophages in the brain. Neuro Oncol. 2016, 18, 58-69. [CrossRef] [PubMed]

169. Abels, E.R.; Maas, S.L.N.; Nieland, L.; Wei, Z.; Cheah, P.S.; Tai, E.; Kolsteeg, C.J.; Dusoswa, S.A.; Ting, D.T.; Hickman, S.; et al. Glioblastoma-associated microglia reprogramming is mediated by functional transfer of extracellular miR-21. Cell Rep. 2019, 28, 3105-3119.e7. [CrossRef] [PubMed]

170. Gabriely, G.; Wurdinger, T.; Kesari, S.; Esau, C.C.; Burchard, J.; Linsley, P.S.; Krichevsky, A.M. MicroRNA 21 promotes glioma invasion by targeting matrix metalloproteinase regulators. Mol. Cell. Biol. 2008, 28, 5369-5380. [CrossRef] [PubMed]

171. Papagiannakopoulos, T.; Shapiro, A.; Kosik, K.S. MicroRNA-21 targets a network of key tumor-suppressive Pathways in glioblastoma cells. Cancer Res. 2008, 68, 8164-8172. [CrossRef]

172. Sun, X.; Ma, X.; Wang, J.; Zhao, Y.; Wang, Y.; Bihl, J.C.; Chen, Y.; Jiang, C. Glioma stem cells-derived exosomes promote the angiogenic ability of endothelial cells through miR-21/VEGF signal. Oncotarget 2017, 8, 36137-36148. [CrossRef]

173. Akers, J.C.; Ramakrishnan, V.; Kim, R.; Skog, J.; Nakano, I.; Pingle, S.; Kalinina, J.; Hua, W.; Kesari, S.; Mao, Y.; et al. MiR-21 in the extracellular vesicles (EVs) of cerebrospinal fluid (CSF): A platform for glioblastoma biomarker development. PloS ONE 2013, 8, e78115. [CrossRef]

174. Shi, R.; Wang, P.Y.; Li, X.Y.; Chen, J.X.; Li, Y.; Zhang, X.Z.; Zhang, C.G.; Jiang, T.; Li, W.B.; Ding, W.; et al. Exosomal levels of miRNA-21 from cerebrospinal fluids associated with poor prognosis and tumor recurrence of glioma patients. Oncotarget 2015, 6, 26971-26981. [CrossRef] [PubMed]

175. Cai, Q.; Zhu, A.; Gong, L. Exosomes of glioma cells deliver miR-148a to promote proliferation and metastasis of glioblastoma via targeting CADM1. Bull. Cancer 2018, 105, 643-651. [CrossRef] [PubMed]

176. Lan, F.; Qing, Q.; Pan, Q.; Hu, M.; Yu, H.; Yue, X. Serum exosomal miR-301a as a potential diagnostic and prognostic biomarker for human glioma. Cell. Oncol. 2018, 41, 25-33. [CrossRef] [PubMed] 
177. Manterola, L.; Guruceaga, E.; Gállego Pérez-Larraya, J.; González-Huarriz, M.; Jauregui, P.; Tejada, S.; Diez-Valle, R.; Segura, V.; Samprón, N.; Barrena, C.; et al. A small noncoding RNA signature found in exosomes of GBM patient serum as a diagnostic tool. Neuro Oncol. 2014, 16, 520-527. [CrossRef] [PubMed]

178. Yin, J.; Zeng, A.; Zhang, Z.; Shi, Z.; Yan, W.; You, Y. Exosomal transfer of miR-1238 contributes to temozolomide-resistance in glioblastoma. EBioMedicine 2019, 42, 238-251. [CrossRef] [PubMed]

179. Bronisz, A.; Wang, Y.; Nowicki, M.O.; Peruzzi, P.; Ansari, K.I.; Ogawa, D.; Balaj, L.; De Rienzo, G.; Mineo, M.; Nakano, I.; et al. Extracellular vesicles modulate the glioblastoma microenvironment via a tumor suppression signaling network directed by miR-1. Cancer Res. 2014, 74, 738-750. [CrossRef]

180. Zeng, A.; Wei, Z.; Yan, W.; Yin, J.; Huang, X.; Zhou, X.; Li, R.; Shen, F.; Wu, W.; Wang, X.; et al. Exosomal transfer of miR-151a enhances chemosensitivity to temozolomide in drug-resistant glioblastoma. Cancer Lett. 2018, 436, 10-21. [CrossRef]

181. Fang, B.; Zhu, J.; Wang, Y.; Geng, F.; Li, G. MiR-454 inhibited cell proliferation of human glioblastoma cells by suppressing PDK1 expression. Biomed. Pharm. 2015, 75, 148-152. [CrossRef]

182. Shao, N.; Xue, L.; Wang, R.; Luo, K.; Zhi, F.; Lan, Q. MiR-454-3p is an exosomal biomarker and functions as a tumor suppressor in glioma. Mol. Cancer 2019, 18, 459-469. [CrossRef]

183. Macario, A.J.L.; Conway de Macario, E. Chaperone proteins and chaperonopathies. In Stress: Physiology, Biochemistry, and Pathology; Elsevier: Amsterdam, The Netherlands, 2019; pp. 135-152.

184. Dahiya, V.; Buchner, J. Functional principles and regulation of molecular chaperones. In Advances in Protein Chemistry and Structural Biology; Academic Press Inc.: Cambridge, MA, USA, 2019; Volume 114, pp. 1-60, ISBN 9780128155578.

185. Hendrick, J.P.; Hartl, F.U. Molecular chaperone functions of heat-shock proteins. Annu. Rev. Biochem. 1993, 62, 349-384. [CrossRef]

186. Becker, J.; Craig, E.A. Heat-shock proteins as molecular chaperones. Eur. J. Biochem. 1994, 219, 11-23. [CrossRef] [PubMed]

187. Nollen, E.A.; Morimoto, R.I. Chaperoning signaling pathways: Molecular chaperones as stress-sensing "heat shock" proteins. J. Cell Sci. 2002, 115, 2809-2816. [PubMed]

188. Jacob, P.; Hirt, H.; Bendahmane, A. The heat-shock protein/chaperone network and multiple stress resistance. Plant. Biotechnol. J. 2017, 15, 405-414. [CrossRef] [PubMed]

189. Ellis, J. Proteins as molecular chaperones. Nature 1988, 328, 378-379. [CrossRef] [PubMed]

190. Ellis, R.J. The molecular chaperone concept. Semin. Cell Biol. 1990, 1, 1-9.

191. Ellis, R.J. Molecular chaperones: Assisting assembly in addition to folding. Trends Biochem. Sci. 2006, 31, 395-401. [CrossRef]

192. Kim, Y.E.; Hipp, M.S.; Bracher, A.; Hayer-Hartl, M.; Ulrich Hartl, F. Molecular chaperone functions in protein folding and proteostasis. Annu. Rev. Biochem. 2013, 82, 323-355. [CrossRef]

193. Finka, A.; Sharma, S.K.; Goloubinoff, P. Multi-layered molecular mechanisms of polypeptide holding, unfolding and disaggregation by HSP70/HSP110 chaperones. Front. Mol. Biosci. 2015, 2, 29. [CrossRef]

194. Mogk, A.; Bukau, B.; Kampinga, H.H. Cellular handling of protein aggregates by disaggregation machines. Mol. Cell 2018, 69, 214-226. [CrossRef]

195. Kaushik, S.; Cuervo, A.M. The coming of age of chaperone-mediated autophagy. Nat. Rev. Mol. Cell Biol. 2018, 19, 365-381. [CrossRef]

196. Willison, K.R. The structure and evolution of eukaryotic chaperonin-containing TCP-1 and its mechanism that folds actin into a protein spring. Biochem. J. 2018, 475, 3009-3034. [CrossRef] [PubMed]

197. Adams, B.M.; Oster, M.E.; Hebert, D.N. Protein quality control in the endoplasmic reticulum. Protein J. 2019, 38, 317-329. [CrossRef] [PubMed]

198. Juste, Y.R.; Cuervo, A.M. Analysis of chaperone-mediated autophagy. In Methods in Molecular Biology; Humana Press Inc.: Totowa, NJ, USA, 2019; Volume 1880, pp. 703-727.

199. Pockley, A.G.; Henderson, B. Extracellular cell stress (Heat shock) proteins-immune responses and disease: An overview. Philos. Trans. R. Soc. B Biol. Sci. 2018, 373, 20160522. [CrossRef] [PubMed]

200. Henderson, B.; Calderwood, S.K.; Coates, A.R.M.; Cohen, I.; van Eden, W.; Lehner, T.; Pockley, A.G. Caught with their PAMPs down? The extracellular signalling actions of molecular chaperones are not due to microbial contaminants. Cell Stress Chaperones 2010, 15, 123-141. [CrossRef]

201. Henderson, B.; Pockley, A.G. Molecular chaperones and protein-folding catalysts as intercellular signaling regulators in immunity and inflammation. J. Leukoc. Biol. 2010, 88, 445-462. [CrossRef] 
202. Macario, A.J.L.; Conway de Macario, E. Sick chaperones, cellular stress, and disease. New Engl. J. Med. 2005, 353, 1489-1501. [CrossRef]

203. Macario, A.J.L.; Conway de Macario, E.; Cappello, F. The Chaperonopathies. Diseases with Defective Molecular Chaperones; Springer: Berlin/Heidelberg, Germany, 2013.

204. Hermisson, M.; Strik, H.; Rieger, J.; Dichgans, J.; Meyermann, R.; Weller, M. Expression and functional activity of heat shock proteins in human glioblastoma multiforme. Neurology 2000, 54, 1357-1364. [CrossRef]

205. Yang, I.; Fang, S.; Parsa, A.T. Heat shock proteins in glioblastomas. Neurosurg. Clin. 2010, 21, 111-123. [CrossRef]

206. Rajesh, Y.; Biswas, A.; Mandal, M. Glioma progression through the prism of heat shock protein mediated extracellular matrix remodeling and epithelial to mesenchymal transition. Exp. Cell Res. 2017, 359, $299-311$. [CrossRef]

207. Iglesia, R.P.; de Lima Fernandes, C.F.; Coelho, B.P.; Prado, M.B.; Escobar, M.I.M.; Almeida, G.H.D.R.; Lopes, M.H. Heat shock proteins in glioblastoma biology: Where do we stand? Int. J. Mol. Sci. 2019, 20, 5794. [CrossRef]

208. Alexiou, G.A. Role of heat shock proteins in brain tumors. In Heat Shock Proteins in Neuroscience; Springer International Publishing: Cham, Switzerland, 2019; pp. 23-28.

209. Khalid, H.; Tsutsumi, K.; Yamashita, H.; Kishikawa, M.; Yasunaga, A.; Shibata, S. Expression of the small heat shock protein (hsp) 27 in human astrocytomas correlates with histologic grades and tumor growth fractions. Cell. Mol. Neurobiol. 1995, 15, 257-268. [CrossRef] [PubMed]

210. Assimakopoulou, M.; Sotiropoulou-Bonikou, G.; Maraziotis, T.; Varakis, I. Prognostic significance of Hsp-27 in astrocytic brain tumors: An immunohistochemical study. Anticancer Res. 1997, 17, 2677-2682. [PubMed]

211. Nomura, N.; Nomura, M.; Sugiyama, K.; Hamada, J.I. Phorbol 12-myristate 13-acetate (PMA)-induced migration of glioblastoma cells is mediated via p38MAPK/Hsp27 pathway. Biochem. Pharm. 2007, 74, 690-701. [CrossRef] [PubMed]

212. Sang, D.P.; Li, R.J.; Lan, Q. Quercetin sensitizes human glioblastoma cells to temozolomide in vitro via inhibition of Hsp27. Acta Pharm. Sin. 2014, 35, 832-838. [CrossRef] [PubMed]

213. Belkacemi, L.; Hebb, M.O. HSP27 knockdown produces synergistic induction of apoptosis by HSP90 and kinase inhibitors in glioblastoma multiforme. Anticancer Res. 2014, 34, 4915-4927. [PubMed]

214. Önay Uçar, E.; Şengelen, A. Resveratrol and siRNA in combination reduces Hsp27 expression and induces caspase-3 activity in human glioblastoma cells. Cell Stress Chaperones 2019, 24, 763-775. [CrossRef]

215. Wu, Z.B.; Cai, L.; Lin, S.J.; Leng, Z.G.; Guo, Y.H.; Yang, W.L.; Chu, Y.W.; Yang, S.-H.; Zhao, W.G. Heat shock protein 47 promotes glioma angiogenesis. Brain Pathol. 2016, 26, 31-42. [CrossRef]

216. Zhao, D.; Jiang, X.; Yao, C.; Zhang, L.; Liu, H.; Xia, H.; Wang, Y. Heat shock protein 47 regulated by miR-29a to enhance glioma tumor growth and invasion. J. Neurooncol. 2014, 118, 39-47. [CrossRef]

217. Jiang, X.; Zhou, T.; Wang, Z.; Qi, B.; Xia, H. HSP47 promotes glioblastoma stemlike cell survival by modulating tumor microenvironment extracellular matrix through TGF- $\beta$ pathway. Acs Chem. Neurosci. 2017, 8, 128-134. [CrossRef]

218. Ghosh, J.C.; Siegelin, M.D.; Dohi, T.; Altieri, D.C. Heat shock protein 60 regulation of the mitochondrial permeability transition pore in tumor cells. Cancer Res. 2010, 70, 8988-8993. [CrossRef]

219. Tang, H.; Li, J.; Liu, X.; Wang, G.; Luo, M.; Deng, H. Down-regulation of HSP60 suppresses the proliferation of glioblastoma cells via the ROS/AMPK/mTOR pathway. Sci. Rep. 2016, 6, 28388. [CrossRef] [PubMed]

220. Rappa, F.; Unti, E.; Baiamonte, P.; Cappello, F.; Scibetta, N. Different immunohistochemical levels of Hsp60 and Hsp70 in a subset of brain tumors and putative role of Hsp60 in neuroepithelial tumorigenesis. Eur. J. Histochem. 2013, 57, e20. [CrossRef] [PubMed]

221. Caruso Bavisotto, C.; Marino Gammazza, A.; Cascio, F.L.; Mocciaro, E.; Vitale, A.M.; Vergilio, G.; Pace, A.; Cappello, F.; Campanella, C.; Palumbo Piccionello, A. Curcumin affects HSP60 folding activity and levels in neuroblastoma cells. Int. J. Mol. Sci. 2020, 21, 661. [CrossRef]

222. Marino Gammazza, A.; Caruso Bavisotto, C.; David, S.; Barone, R.; Rappa, F.; Campanella, C.; Conway de Macario, E.; Cappello, F.; Macario, A.J.L. HSP60 is a ubiquitous player in the physiological and pathogenic interactions between the chaperoning and the immune systems. Curr. Immunol. Rev. 2017, 13, 44-55.

223. Caruso Bavisotto, C.; Alberti, G.; Vitale, A.M.; Paladino, L.; Campanella, C.; Rappa, F.; Gorska, M.; Conway de Macario, E.; Cappello, F.; Macario, A.J.L.; et al. Hsp60 Post-translational Modifications: Functional and Pathological Consequences. Front. Mol. Biosci. 2020, 7, 95. [CrossRef] [PubMed] 
224. Vilasi, S.; Bulone, D.; Caruso Bavisotto, C.; Campanella, C.; Marino Gammazza, A.; San Biagio, P.L.; Cappello, F.; Conway de Macario, E.; Macario, A.J.L. Chaperonin of group I: Oligomeric spectrum and biochemical and biological implications. Front. Mol. Biosci. 2018, 4, 99. [CrossRef] [PubMed]

225. Albakova, Z.; Armeev, G.A.; Kanevskiy, L.M.; Kovalenko, E.I.; Sapozhnikov, A.M. HSP70 multi-functionality in cancer. Cells 2020, 9, 587. [CrossRef]

226. Thorsteinsdottir, J.; Stangl, S.; Fu, P.; Guo, K.; Albrecht, V.; Eigenbrod, S.; Erl, J.; Gehrmann, M.; Tonn, J.C.; Multhoff, G.; et al. Overexpression of cytosolic, plasma membrane bound and extracellular heat shock protein 70 (Hsp70) in primary glioblastomas. J. Neurooncol. 2017, 135, 443-452. [CrossRef]

227. Da Rocha, A.B.; Regner, A.; Grivicich, I.; Pretto Schunemann, D.; Diel, C.; Kovaleski, G.; De Farias, C.B.; Mondadori, E.; Almeida, L.; Braga Filho, A.; et al. Radioresistance is associated to increased Hsp70 content in human glioblastoma cell lines. Int. J. Oncol. 2004, 25, 777-785. [CrossRef]

228. Sun, G.; Cao, Y.; Xu, Y.; Huai, D.; Chen, P.; Guo, J.; Li, M.; Dai, Y. Overexpression of Hsc70 promotes proliferation, migration, and invasion of human glioma cells. J. Cell. Biochem. 2019, 120, 10707-10714. [CrossRef]

229. Li, G.; Xu, Y.; Guan, D.; Liu, Z.; Liu, D.X. HSP70 protein promotes survival of C6 and U87 glioma cells by inhibition of ATF5 degradation. J. Biol. Chem. 2011, 286, 20251-20259. [CrossRef] [PubMed]

230. Lazarev, V.F.; Nikotina, A.D.; Mikhaylova, E.R.; Nudler, E.; Polonik, S.G.; Guzhova, I.V.; Margulis, B.A. Hsp70 chaperone rescues $\mathrm{C} 6$ rat glioblastoma cells from oxidative stress by sequestration of aggregating GAPDH. Biochem. Biophys. Res. Commun. 2016, 470, 766-771. [CrossRef]

231. Gopal, U.; Bohonowych, J.E.; Lema-Tome, C.; Liu, A.; Garrett-Mayer, E.; Wang, B.; Isaacs, J.S. A novel extracellular Hsp90 mediated co-receptor function for LRP1 regulates EphA2 dependent glioblastoma cell invasion. PloS ONE 2011, 6, e17649. [CrossRef] [PubMed]

232. Thuringer, D.; Hammann, A.; Benikhlef, N.; Fourmaux, E.; Bouchot, A.; Wettstein, G.; Solary, E.; Garrido, C. Transactivation of the epidermal growth factor receptor by heat shock protein 90 via toll-like receptor 4 contributes to the migration of glioblastoma cells. J. Biol. Chem. 2011, 286, 3418-3428. [CrossRef] [PubMed]

233. Memmel, S.; Sisario, D.; Zöller, C.; Fiedler, V.; Katzer, A.; Heiden, R.; Becker, N.; Eing, L.; Ferreira, F.L.R.; Zimmermann, H.; et al. Migration pattern, actin cytoskeleton organization and response to PI3K-, mTOR-, and Hsp90-inhibition of glioblastoma cells with different invasive capacities. Oncotarget 2017, 8, 45298-45310. [CrossRef] [PubMed]

234. Snigireva, A.V.; Vrublevskaya, V.V.; Skarga, Y.Y.; Morenkov, O.S. Cell surface heparan sulfate proteoglycans are involved in the extracellular Hsp90-stimulated migration and invasion of cancer cells. Cell Stress Chaperones 2019, 24, 309-322. [CrossRef] [PubMed]

235. Wachsberger, P.R.; Lawrence, Y.R.; Liu, Y.; Rice, B.; Feo, N.; Leiby, B.; Dicker, A.P. Hsp90 inhibition enhances PI-3 kinase inhibition and radiosensitivity in glioblastoma. J. Cancer Res. Clin. Oncol. 2014, 140, 573-582. [CrossRef]

236. Sauvageot, C.M.-E.; Weatherbee, J.L.; Kesari, S.; Winters, S.E.; Barnes, J.; Dellagatta, J.; Ramakrishna, N.R.; Stiles, C.D.; Kung, A.L.-J.; Kieran, M.W.; et al. Efficacy of the HSP90 inhibitor 17-AAG in human glioma cell lines and tumorigenic glioma stem cells. Neuro Oncol. 2009, 11, 109-121. [CrossRef]

237. Zhu, H.; Woolfenden, S.; Bronson, R.T.; Jaffer, Z.M.; Barluenga, S.; Winssinger, N.; Rubenstein, A.E.; Chen, R.; Charest, A. The novel Hsp90 inhibitor NXD30001 induces tumor regression in a genetically engineered mouse model of glioblastoma multiforme. Mol. Cancer Ther. 2010, 9, 2618-2626. [CrossRef]

238. Canella, A.; Welker, A.M.; Yoo, J.Y.; Xu, J.; Abas, F.S.; Kesanakurti, D.; Nagarajan, P.; Beattie, C.E.; Sulman, E.P.; Liu, J.; et al. Efficacy of onalespib, a long-acting second-generation HSP90 inhibitor, as a single agent and in combination with temozolomide against malignant gliomas. Clin. Cancer Res. 2017, 23, 6215-6226. [CrossRef]

239. Hauser, P.; Hanzély, Z.; Jakab, Z.; Oláh, L.; Szabó, E.; Jeney, A.; Schuler, D.; Fekete, G.; Bognár, L.; Garami, M. Expression and prognostic examination of heat shock proteins (HSP 27, HSP 70, and HSP 90) in medulloblastoma. J. Pediatr. Hematol. Oncol. 2006, 28, 461-466. [CrossRef] [PubMed]

240. Alexiou, G.A.; Vartholomatos, G.; Stefanaki, K.; Patereli, A.; Dova, L.; Karamoutsios, A.; Lallas, G.; Sfakianos, G.; Moschovi, M.; Prodromou, N. Expression of heat shock proteins in medulloblastoma: Laboratory investigation. J. Neurosurg. Pediatr. 2013, 12, 452-457. [CrossRef] [PubMed] 
241. Hallal, S.; Russell, B.P.; Wei, H.; Lee, M.Y.T.; Toon, C.W.; Sy, J.; Shivalingam, B.; Buckland, M.E.; Kaufman, K.L. Extracellular vesicles from neurosurgical aspirates identifies chaperonin containing TCP1 subunit 6A as a potential glioblastoma biomarker with prognostic significance. Proteomics 2019, 19, e1800157. [CrossRef] [PubMed]

242. Graner, M.W.; Cumming, R.I.; Bigner, D.D. The heat shock response and chaperones/heat shock proteins in brain tumors: Surface expression, release, and possible immune consequences. J. Neurosci. 2007, 27, 11214-11227. [CrossRef]

243. Graner, M.W.; Alzate, O.; Dechkovskaia, A.M.; Keene, J.D.; Sampson, J.H.; Mitchell, D.A.; Bigner, D.D. Proteomic and immunologic analyses of brain tumor exosomes. FASEB J. 2009, 23, 1541-1557. [CrossRef] [PubMed]

244. Epple, L.M.; Griffiths, S.G.; Dechkovskaia, A.M.; Dusto, N.L.; White, J.; Ouellette, R.J.; Anchordoquy, T.J.; Bemis, L.T.; Graner, M.W. Medulloblastoma exosome proteomics yield functional roles for extracellular vesicles. PLoS ONE 2012, 7, e42064. [CrossRef] [PubMed]

245. Graner, M.; Redzic, J.; Ung, T. Glioblastoma extracellular vesicles: Reservoirs of potential biomarkers. Pharmgenomics Pers. Med. 2014, 7, 65. [CrossRef]

246. Lane, R.; Simon, T.; Vintu, M.; Solkin, B.; Koch, B.; Stewart, N.; Benstead-Hume, G.; Pearl, F.M.G.; Critchley, G.; Stebbing, J.; et al. Cell-derived extracellular vesicles can be used as a biomarker reservoir for glioblastoma tumor subtyping. Commun. Biol. 2019, 2, 315. [CrossRef]

247. Wei, Z.; Batagov, A.O.; Schinelli, S.; Wang, J.; Wang, Y.; El Fatimy, R.; Rabinovsky, R.; Balaj, L.; Chen, C.C.; Hochberg, F.; et al. Coding and noncoding landscape of extracellular RNA released by human glioma stem cells. Nat. Commun. 2017, 8, 1145. [CrossRef]

248. Bronisz, A.; Godlewski, J.; Chiocca, E.A. Extracellular vesicles and microRNAs: Their role in Tumorigenicity and therapy for brain tumors. Cell. Mol. Neurobiol. 2016, 36, 361-376. [CrossRef]

249. Gourlay, J.; Morokoff, A.P.; Luwor, R.B.; Zhu, H.J.; Kaye, A.H.; Stylli, S.S. The emergent role of exosomes in glioma. J. Clin. Neurosci. 2017, 35, 13-23. [CrossRef]

250. Skog, J.; Würdinger, T.; van Rijn, S.; Meijer, D.H.; Gainche, L.; Sena-Esteves, M.; Curry, W.T.; Carter, B.S.; Krichevsky, A.M.; Breakefield, X.O. Glioblastoma microvesicles transport RNA and proteins that promote tumour growth and provide diagnostic biomarkers. Nat. Cell Biol. 2008, 10, 1470-1476. [CrossRef] [PubMed]

251. Gao, X.; Zhang, Z.; Mashimo, T.; Shen, B.; Nyagilo, J.; Wang, H.; Wang, Y.; Liu, Z.; Mulgaonkar, A.; $\mathrm{Hu}$, X.L.; et al. Gliomas interact with non-glioma brain cells via extracellular vesicles. Cell Rep. 2020, 30, 2489-2500.e5. [CrossRef] [PubMed]

252. Zeng, A.L.; Yan, W.; Liu, Y.W.; Wang, Z.; Hu, Q.; Nie, E.; Zhou, X.; Li, R.; Wang, X.F.; Jiang, T.; et al. Tumour exosomes from cells harbouring PTPRZ1-MET fusion contribute to a malignant phenotype and temozolomide chemoresistance in glioblastoma. Oncogene 2017, 36, 5369-5381. [CrossRef] [PubMed]

253. Zhou, W.; Fong, M.Y.; Min, Y.; Somlo, G.; Liu, L.; Palomares, M.R.; Yu, Y.; Chow, A.; O'Connor, S.T.F.; Chin, A.R.; et al. Cancer-secreted miR-105 destroys vascular endothelial barriers to promote metastasis. Cancer Cell 2014, 25, 501-515. [CrossRef]

254. Tominaga, N.; Kosaka, N.; Ono, M.; Katsuda, T.; Yoshioka, Y.; Tamura, K.; Lötvall, J.; Nakagama, H.; Ochiya, T. Brain metastatic cancer cells release microRNA-181c-containing extracellular vesicles capable of destructing blood-brain barrier. Nat. Commun. 2015, 6, 6716. [CrossRef] [PubMed]

255. Xu, G.; Zhu, H.; Zhang, M.; Xu, J. Histone deacetylase 3 is associated with gastric cancer cell growth via the miR-454-mediated targeting of CHD5. Int. J. Mol. Med. 2018, 41, 155-163. [CrossRef]

256. Tytell, M. Release of heat shock proteins (Hsps) and the effects of extracellular Hsps on neural cells and tissues. Int. J. Hyperth. 2005, 21, 445-455. [CrossRef]

257. Van Den Boorn, J.G.; Schlee, M.; Coch, C.; Hartmann, G. SiRNA delivery with exosome nanoparticles. Nat. Biotechnol. 2011, 29, 325-326. [CrossRef]

258. Pullan, J.E.; Confeld, M.I.; Osborn, J.K.; Kim, J.; Sarkar, K.; Mallik, S. Exosomes as drug carriers for cancer therapy. Mol. Pharm. 2019, 16, 1789-1798. [CrossRef]

259. Kim, G.; Kim, M.; Lee, Y.; Byun, J.W.; Hwang, D.W.; Lee, M. Systemic delivery of microRNA-21 antisense oligonucleotides to the brain using T7-peptide decorated exosomes. J. Control. Release 2020, 317, $273-281$.

[CrossRef] [PubMed] 
260. Bu, N.; Wu, H.; Sun, B.; Zhang, G.; Zhan, S.; Zhang, R.; Zhou, L. Exosome-loaded dendritic cells elicit tumor-specific CD8 + cytotoxic T cells in patients with glioma. J. Neurooncol. 2011, 104, 659-667. [CrossRef] [PubMed]

261. Bu, N.; Wu, H.; Zhang, G.; Zhan, S.; Zhang, R.; Sun, H.; Du, Y.; Yao, L.; Wang, H. Exosomes from dendritic cells loaded with chaperone-rich cell lysates elicit a potent $\mathrm{T}$ cell immune response Against intracranial glioma in mice. J. Mol. Neurosci. 2015, 56, 631-643. [CrossRef] [PubMed]

262. O’Brien, K.; Lowry, M.C.; Corcoran, C.; Martinez, V.G.; Daly, M.; Rani, S.; Gallagher, W.M.; Radomski, M.W.; MacLeod, R.A.F.; O'Driscoll, L. MiR-134 in extracellular vesicles reduces triple-negative breast cancer aggression and increases drug sensitivity. Oncotarget 2015, 6, 32774-32789. [CrossRef] [PubMed]

263. Su, S.F.; Chang, Y.W.; Andreu-Vieyra, C.; Fang, J.Y.; Yang, Z.; Han, B.; Lee, A.S.; Liang, G. MiR-30d, miR-181a and miR-199a-5p cooperatively suppress the endoplasmic reticulum chaperone and signaling regulator GRP78 in cancer. Oncogene 2013, 32, 4694-4701. [CrossRef]

264. Cai, H.; Xue, Y.; Wang, P.; Wang, Z.; Li, Z.; Hu, Y.; Li, Z.; Shang, X.; Liu, Y. The long noncoding RNA TUG1 regulates blood-tumor barrier permeability by targeting miR-144. Oncotarget 2015, 6, 19759-19779. [CrossRef]

(C) 2020 by the authors. Licensee MDPI, Basel, Switzerland. This article is an open access article distributed under the terms and conditions of the Creative Commons Attribution (CC BY) license (http://creativecommons.org/licenses/by/4.0/). 